\title{
The Influence of Soil Moisture, Coastline Curvature, and Land-Breeze Circulations on Sea-Breeze Initiated Precipitation
}

\author{
R. David Baker \\ Mesoscale Atmospheric Processes Branch \\ NASA/Goddard Space Flight Center \\ Universities Space Research Association \\ Greenbelt, Maryland \\ Barry H. Lynn \\ Mesoscale Atmospheric Processes Branch \\ NASA/Goddard Space Flight Center \\ Center for Climate Systems Research, Columbia University \\ Greenbelt, Maryland \\ Aaron Boone \\ CNRM, Meteo-France \\ Toulouse, France \\ Wei-Kuo Tao \\ Mesoscale Atmospheric Processes Branch \\ NASA/Goddard Space Flight Center \\ Greenbelt, Maryland \\ Joanne Simpson \\ Laboratory for Atmospheres \\ NASA/Goddard Space Flight Center \\ Greenbelt, Maryland \\ Manuscript Submitted March 3, 2000 \\ to the Journal of Hydrometeorology
}

Corresponding author address: Dr. R. David Baker, NASA/Goddard Space Flight Center, Code 912, Greenbelt, Maryland 20771, email: rbaker@agnes.gsfc.nasa.gov 


\begin{abstract}
Idealized numerical simulations are performed with a coupled atmosphere/land-surface model to identify the roles of initial soil moisture, coastline curvature, and land breeze circulations on sea breeze initiated precipitation. Data collected on 27 July 1991 during the Convection and Precipitation Electrification Experiment (CaPE) in central Florida are used. The 3D Goddard Cumulus Ensemble (GCE) cloud resolving model is coupled with the Goddard Parameterization for Land-Atmosphere-Cloud Exchange (PLACE) land surface model, thus providing a tool to simulate more realistically land-surface/atmosphere interaction and convective initiation. Eight simulations are conducted with either straight or curved coastlines, initially homogeneous soil moisture or initially variable soil moisture, and initially homogeneous horizontal winds or initially variable horizontal winds (land breezes).

All model simulations capture the diurnal evolution and general distribution of sea-breeze initiated precipitation over central Florida. The distribution of initial soil moisture influences the timing, intensity, and location of subsequent precipitation. Soil moisture acts as a moisture source for the atmosphere, increases the convectively available potential energy, and thus preferentially focuses heavy precipitation over existing wet soil. Strong soil moistureinduced mesoscale circulations are not evident in these simulations. Coastline curvature has a major impact on the timing and location of precipitation. Earlier low-level convergence occurs inland of convex coastlines, and subsequent precipitation occurs earlier in simulations with curved coastlines. The presence of initial land breezes alone has little impact on subsequent precipitation. However, simulations with both coastline curvature and initial land breezes produce significantly larger peak rain rates due to nonlinear interactions.
\end{abstract}




\section{Introduction}

It has long been recognized that sea breezes strongly influence development of deep cumulus convection over the Florida peninsula (e.g., Byers and Rodebush, 1948; Pielke, 1974; Simpson et al., 1980; Blanchard and Lopez, 1985; Fankhauser et al., 1995; Kingsmill, 1995; Wilson and Megenhardt, 1997). Under synoptically undisturbed conditions, convection can develop along boundary layer convergence lines associated with sea breezes from the east and west coasts of Florida. Depending on the mean wind direction, cold outflow from convection along a sea-breeze front may interact with the sea-breeze convergence zone from the other coast and produce strong thunderstorms (Fankhauser et al., 1995; Kingsmill, 1995; Wilson and Megenhardt, 1997). The location and intensity of precipitation associated with Florida sea breeze circulations is thus directly influenced by factors which control low level convergence. In this paper, we explore the role of three factors on sea-breeze initiated precipitation over the Florida peninsula: soil moisture availability, coastline curvature, and early morning land breeze circulations.

Soil moisture may impact convective development by enhancing atmospheric moisture or by modulating the surface temperature to produce mesoscale circulations. Through strong evapotranspiration, wet soil may act as a moisture source for the overlying atmospheri. boundary layer, thus increasing the moist static energy of the atmosphere and promotipg convective development. Horizontal variations in soil moisture have been shown to produce strong mesoscale circulations (e.g., Ookouchi et al., 1984; Yan and Anthes, 1988; Avissar and Liu, 1996; Lynn et al., 1998). Clouds and subsequent rainfall may develop along the 
soil moisture-induced frontal boundary (Avissar and Liu, 1996; Lynn et al., 1998). The role of soil moisture on Florida precipitation remains unclear. Two dimensional simulations indicate that moist surface conditions and dry surface conditions produce comparable rainfall amounts over the Florida peninsula (Nicholls et al., 1991), but three-dimensional simulations suggest peak precipitation amounts six times larger for dry soil than for moist soil (Xu et al., 1996). In both 2-D and 3-D simulations, soil moisture significantly altered the distribution of precipitation (Nicholls et al., 1991; Xu et al., 1996).

Coastline curvature also may modulate sea-breeze convergence. Idealized numerical simulations indicate that convex coastlines exhibit strong convergence while concave coastlines experience sea breeze divergence (McPherson, 1970). Similarly, Pielke (1974) and Boybeyi and Raman (1992) show strong convergence associated with convex coastlines of the Florida peninsula. Thus, it seems likely that coastline irregularity strongly affects the location of precipitation. Since the area of surface convergence strongly determines the total rainfall amount (Ulanski and Garstang, 1978), coastline curvature also may be a primary factor in determining rainfall intensity.

The influence of the mean wind on sea breeze development has been well documented. Stronger convergence occurs when low level prevailing winds oppose the sea breeze, while weaker convergence occurs when low level winds flow in the same direction as the sea breeze (Pielke, 1974; Boybeyi and Raman, 1992; Atkins and Wakimoto, 1997). The role of mesoscale variations in wind has received less attention. Heterogeneous initial conditions often produce better simulations in mesoscale models (e.g., Nair et al., 1997), implying that mesoscale 
variations play an important role in storm development. Thus, the presence of a welldeveloped early morning land breeze (i.e., mesoscale variation in wind) may modify the location and strength of subsequent sea breeze convergence zones and therefore may impact the location and intensity of precipitation.

To assess the relative importance of these factors on sea-breeze initiated precipitation, we consider the 27 July 1991 squall line over central Florida during the Convection and Precipitation Electrification Experiment (CaPE). This case has been simulated previously with a two-dimensional cloud resolving model to diagnose water and energy budgets of a Florida squall line (Halverson et al., 1996). Here, we use a three-dimensional cloud resolving model coupled with a sophisticated land surface model to test the sensitivity of sea-breeze initiated precipitation to initial soil moisture distribution, coastline irregularities, and initial wind distribution. The next section describes squall line development and observed precipitation on 27 July 1991. Section 3 introduces the coupled atmosphere-land surface model, and section 4 presents results from model simulations. Implications of these results for Florida precipitation, land surface-atmosphere interaction, and numerical weather prediction are presented in the Discussion section.

\section{Observations}

The 27 July 1991 CaPE squall line has been thoroughly analyzed by Halverson et al. (1996). In the discussion below, all times will be given in local standard time (LST) because of the diurnal nature of sea-breeze initiated convection (UTC is 5 hours ahead of LST). Sea breezes 
developed along both coasts of central Florida, with the west coast sea breeze (WCSB) penetrating further into the peninsula interior than the east coast sea breeze (ECSB). Westerly low-level winds (Figure 1) produced this pattern by enhancing inward propagation of the WCSB and opposing inward penetration of the ECSB. By 1300 LST, convective cells developed along the WCSB front (Figure 2a). The WCSB front continued to propagate further inland, and the western half of central Florida was covered by convective clouds by 1500 LST. Clouds along the ECSB front were beginning to develop by this time (Figure $2 b$ ). Cold outflow from WCSB convective cells collided with the ECSB front (Wilson and Megenhardt, 1997), and a well-developed squall line occurred along the east coast by 1700 LST (Figure 2c). The squall line first developed just after 1500 LST and began to dissipate at roughly 1800 LST (Halverson et al., 1996). This pattern of convective development is characteristic of Type 3 Florida convection in which a strong north-south line of echoes develops along the east coast in response to a merger of the WCSB and the ECSB (Blanchard and Lopez, 1985).

Figure 3 shows observed accumulated rainfall on 27 July 1991 from 0600-2100 LST collected by rain gauges from CaPE PAM stations and NOAA weather stations. The CaPE network comprised a dense array of observing stations in east-central Florida, while the NOAA sites are more evenly (and sparsely) distributed throughout the peninsula. Further details on the observational network during CaPE can be found in Halverson et al. (1996). Barnes objective analysis is used to interpolate between stations. As Figure 3 indicates, relatively weak rainfall $(0-25 \mathrm{~mm})$ associated with WCSB convection occurred over west-central 
Florida. Larger rainfall amounts occurred over east-central Florida, with strong rainfall peaks of 53-62 mm. Rainfall in eastern Florida on this day was associated with the late afternoon squall line. Radar images (not shown) with strong cells of over $50 \mathrm{dBZ}$ in eastern Florida confirm the distribution of rainfall measured by rain gauges (Halverson et al., 1996).

\section{Model}

\section{a. GCE-PLACE}

The purpose of this paper is to isolate the physical processes that contribute to the timing, intensity, and location of precipitation during one day in central Florida. To accomplish this goal, we utilize the GCE-PLACE coupled atmosphere/land-surface model. The atmospheric model is the three-dimensional Goddard Cumulus Ensemble (GCE) cloud resolving model (Tao and Simpson, 1993). The GCE cloud model is a high-resolution, anelastic, nonhydrostatic model that has been extensively applied to study cloud-environment interaction, cloud mergers, air-sea interaction, cloud-radiation interaction, and trace gas transport (e.g., Simpson and Tao, 1993). The model includes solar and infrared radiative transfer processes, a Kessler two-category liquid water scheme, and three-category ice microphysics schemes (Lin et al., 1983; Rutledge and Hobbs, 1984). The Rutledge-Hobbs microphysics scheme is utilized in this study given the tropical characteristics of the sounding (Figure 1). GCE is an active participant in the GEWEX Cloud System Study (GCSS) cloud resolving model inter-

comparison project (Moncrieff et al., 1997). Halverson et al. (1996) used a two-dimensional 
version of GCE (without the land-surface model) to assess heating rates associated with the 27 July 1991 squall line.

The land-surface component of GCE-PLACE is the Goddard Parameterization for LandAtmosphere-Cloud Exchange (PLACE; Wetzel and Boone, 1995). PLACE provides state-ofthe-art representation of land surface processes. The land-surface water budget incorporates precipitation, evapotranspiration, plant uptake, infiltration, and runoff. Soil temperatures evolve through an imbalance of surface net radiation, ground heat flux, sensible heat flux, and latent heat flux. Momentum, sensible heat, and latent heat fluxes are calculated using similarity relationships (Businger et al., 1971; Zilitinkevich, 1975). The soil component includes seven soil layers (five for soil moisture and seven for soil temperature), and the vegetation component is represented by a single layer. Eight different soil types and fourteen different vegetation types may be selected. PLACE is a participant in the Project for Intercomparison of Land-surface Parameterization Schemes (PILPS; Chen et al., 1997).

The atmospheric component of GCE-PLACE provides surface winds, surface air temperature, surface pressure, atmospheric moisture, shortwave and longwave radiation, and precipitation to the land surface. The land-surface component returns momentum, sensible heat, and latent heat fluxes to the atmosphere. The coupling is two-way interactive. For example, precipitation can alter the distribution of soil moisture, which in turn changes the partitioning of energy between sensible heat and latent heat. These heat fluxes then feed back on subsequent development of clouds and precipitation. A two-dimensional version of GCE-PLACE has previously been used to investigate landscape-generated deep convection 
(Lynn et al., 1998).

\section{b. Experimental design}

Eight idealized numerical experiments (Table I) are performed to test the sensitivity of sea-breeze initiated precipitation to soil moisture, coastline curvature, and land breezes. The main purpose here is to isolate the effect of these factors on precipitation rather than to reproduce observations exactly. However, as described in more detail below, all eight simulations reproduce the general evolution of the 27 July 1991 storm, indicating that our idealized simulations capture much of the essential physics responsible for precipitation on this day. Each simulation is labeled by three letters: the first letter documents a straight (S) or curved (C) coastline configuration, the second letter documents an average (A) or variable (V) soil moisture initial condition, and the third letter represents average (A) or variable (V) initial winds. To first order, SAA can be viewed as the simulation which isolates the influence of average sea breezes on precipitation; the other seven simulations consider factors which may modulate sea breeze evolution and subsequent precipitation. The domain size for each simulation is $400 \mathrm{~km}$ in the east-west direction, $320 \mathrm{~km}$ in the north-south direction, and 21 $\mathrm{km}$ vertically. The horizontal grid resolution is $3.1 \mathrm{~km}$ in the east-west direction and $2.5 \mathrm{~km}$ in the north-south direction. Horizontal resolutions $\leq 4 \mathrm{~km}$ have been shown to sufficiently capture squall-line dynamics (Weisman et al., 1997). A stretched vertical grid with 80-m resolution at the surface and $1200-\mathrm{m}$ resolution near the tropopause is implemented. The lateral boundaries are periodic. This boundary condition is not overly restrictive since local 
sea breezes are the primary forcing mechanism for precipitation on this day. The Florida coastline has been tilted horizontally in these simulations to insure periodic integrity in the north-south direction. A sponge layer exists in the upper $5 \mathrm{~km}$ of the experimental domain to absorb vertically propagating internal gravity waves. Each simulation is integrated for 15 hours from 0600 to 2100 LST with a time step of 5 seconds.

Four numerical experiments consider a simplified, straight coastline (Figure 4a). The peninsular width in these simulations is $200 \mathrm{~km}$ with $100 \mathrm{~km}$ of ocean on each side. The other four experiments consider a Florida-like curved coastline with the peninsular width varying from 160 to $220 \mathrm{~km}$ (Figure $4 \mathrm{~b}$ ). Significant lake breezes may develop in response to differential heating near Lake Okeechobee (Pielke, 1974; Boybeyi and Raman, 1992). Indeed, a large convective cell likely associated with a lake breeze formed northwest of Lake Okeechobee on 27 July 1991 (Figure 2). However, this paper focuses on heavy precipitation associated with the squall line, and therefore Lake Okeechobee is neglected in these experiments.

A sandy clay loam soil-type and tall broadleaf trees with ground cover are used in this study. Land surface characteristics such as surface roughness, surface albedo, fractional vegetation cover, and leaf area index are derived from International Satellite Land-Surface Climatology Project (ISLSCP) data (Meeson et al., 1995). Statistical distributions of these quantities for the selected soil texture and vegetation type are used. The total soil depth is 8 meters with soil layer thicknesses ranging from $1 \mathrm{~cm}$ at the top to 7 meters at the bottom. 


\section{c. Initial conditions}

The key differences among the eight experiments (Table I) are different initial conditions at 0600 LST and different lower boundary conditions (straight coastline vs. curved coastline). In all cases, the initial thermodynamic and moisture sounding (Figure 1) is an average sounding from four locations: Tampa and Dunnellon on the west coast, and Daytona Beach and Fellsmere on the east coast. A relatively low value for convectively available potential energy (CAPE) of $259 \mathrm{~J} \mathrm{~kg}^{-1}$ initially occurs. Naturally, CAPE will increase throughout the day as the land surface warms and moistens the atmosphere above.

Offline PLACE simulations provide the initial distribution of soil moisture. Observed precipitation over the previous 6 days is input into PLACE, and this moisture is then distributed among the 5 soil moisture layers. To achieve a steady state distribution of soil moisture, the procedure is iterated 50 times. Figure 4 shows soil moisture distribution in the root zone used in simulations with initially varying soil moisture (SVA, SVV, CVA, and CVV). Root zone soil moisture is shown since the root zone largely determines moisture availability over vegetated surfaces. Two relatively wet strips of land exist within the peninsula: one oriented in the east-west direction at roughly $y=225 \mathrm{~km}$ and the other oriented in the northwest-southeast direction over east-central Florida. A very dry patch of land exists in west-central Florida from $y=0 \mathrm{~km}$ to $y=180 \mathrm{~km}$. Simulations SAA, SAV, CAA, and CAV use the horizontally averaged value of PLACE-derived soil moisture in each soil layer (the root zone average soil moisture is $0.162 \mathrm{~cm}^{3} / \mathrm{cm}^{3}$ ). Random perturbations in soil moisture $\left( \pm 0.01 \mathrm{~cm}^{3} / \mathrm{cm}^{3}\right)$ are applied throughout the peninsula in all simulations. 
Figure 5 shows the initial wind speed and wind direction in the $2-4 \mathrm{~km}$ layer for experiments with variable initial horizontal wind (SAV, SVV, CAV, and CVV). The 2-4 km layer wind is shown since this level steers convective cells over Florida (Wilson and Megenhardt, 1997). The distribution of wind in Figure 5 has been interpolated from wind measurements from the four sounding sites. The wind at this level is generally northwesterly, with larger wind speeds along the west coast and smaller wind speeds along the east coast. This distribution of wind indicates the presence of an early morning land breeze. Air at the top of a land breeze circulation flows toward the coast. Along the west coast, the land breeze augments the mean flow at $2-4 \mathrm{~km}$ altitude and produces larger wind speeds. The opposite occurs along the east coast. The wind distribution for simulations CAV and CVV (curved coastline) is identical to the wind distribution for simulations SAV and SVV (straight coastline). Simulations SAA, SVA, CAA, and CVA use a homogeneous distribution of horizontal wind, the average from the four soundings (Figure 1).

The initial soil temperature is derived from offline PLACE simulations and then horizontally averaged in each of the 7 soil temperature layers. The initial surface temperature over land at 0600 LST is $301.1 \mathrm{~K}$. The initial average sea surface temperature $(301.7 \mathrm{~K})$ for 27 July 1991 is obtained from the Comprehensive Ocean-Atmosphere Data Set (COADS; Woodruff et al., 1993). The sea surface temperature evolves throughout the simulations but remains close to the initial value. 


\section{Results}

\section{a. General evolution: timing, location, and intensity}

All eight model simulations reproduce the general evolution of sea-breeze initiated clouds and precipitation over Florida on 27 July 1991. Figure 6 shows the vertically integrated hydrometeor (cloud water, rain, ice, snow, and graupel) mass per unit area for simulation CVV at 13 LST, 15 LST, and 17 LST. Evolution of total hydrometeors in simulation CVV agrees well with the observed cloud evolution (Figure 2). At 13 LST, a line of convective cells has developed in simulation CVV along the west coast associated with the west coast sea breeze front. Clouds have also formed near Cape Canaveral, consistent with satellite observations. By 15 LST, west coast convection cells have become larger, and east coast convection cells are more numerous. At 17 LST, a line of cells has developed along the east coast, and cloud coverage on the western half of the peninsula has diminished. The other simulations show similar evolution; specific differences among the simulations will be addressed below.

The impact of the three factors (soil moisture, coastline curvature, and land breezes) on the location and intensity of precipitation can be assessed from accumulated rainfall maps. Figure 7 shows the accumulated rainfall from 06 to 21 LST for the eight simulations. All cases reproduce the general pattern of precipitation with relatively low rainfall amounts on the western half of the peninsula and stronger precipitation on the eastern half. Cases CAA, CAV, and CVV most closely agree with the observed rainfall distribution (Figure 3), 
suggesting that coastline curvature plays an instrumental role in determining the location of precipitation. Interestingly, soil moisture and coastline curvature mitigate each other in simulation CVA to produce a rainfall distribution less similar to the observed pattern. The largest peak rainfall amounts occur in simulations SVA $(51.3 \mathrm{~mm})$, SVV $(50.4 \mathrm{~mm})$, and CVV (49.1 mm), implying that soil moisture initial conditions have an impact on precipitation intensity. In addition, simulations with variable soil moisture (SVA, SVV, CVA, and CVV) show heavy rainfall in the northern part of the domain where soil moisture is abundant (Figure 4).

Soil moisture and coastline curvature also influence the timing of precipitation. Figure 8 plots the peak rain rate vs. time for the eight simulations. The peak rain rate is defined as the maximum rain rate in the domain at a given time. All cases reproduce well the observed diurnal evolution of sea-breeze initiated precipitation over Florida. Precipitation begins around noontime, reaches peak values in the afternoon, and rapidly decays in the early evening. Significant differences can be seen among the eight simulations. The highest values for peak rain rates in the simulations with variable initial soil moisture (SVA, SVV, CVA, and CVV) occur 1-2 hours later than in the simulations with average soil moisture. Similarly, simulations with curved coastlines initially produce larger peak rain rates at the onset of precipitation near $12 \mathrm{LST}$. Peak rain rates with equivalent magnitudes occur roughly 1 hour earlier in the simulations with curved coastlines (CAA, CVA, CAV, and CVV) compared to simulations with straight coastlines.

With the exception of Cases CAV and CVV, the maximum peak rain rate (which occurs 
in the afternoon) for the simulations is within a few percent of the observed maximum peak rain rate (Figure 8). Simulations CAV and CVV produce significantly higher maximum peak rain rates with values $27 \%$ and $22 \%$ higher than observed values, respectively. This result suggests that interplay between coastline curvature and initial land breeze circulations can produce significantly higher rain rates than by coastline curvature or by land breeze circulations alone.

Table II provides a summary on the impact of soil moisture, coastline curvature, and land breeze circulations on the timing, location, and intensity of precipitation. Simulation SAA is considered the control simulation to which all other simulations are compared; it captures the first order effect of average sea breezes on precipitation. Each factor is considered a significant influence if it alters the timing of precipitation by $\geq 1$ hour, the location of maximum accumulated precipitation by $\geq 50 \mathrm{~km}$, the peak rain rate by $\geq 5 \mathrm{~mm} \mathrm{hr}^{-1}(\sim 20 \%$ of the maximum), and the accumulated rainfall by $\geq 8 \mathrm{~mm}(\sim 20 \%$ of the peak accumulated rainfall in control simulation SAA). Soil moisture influences the timing, location, and intensity of precipitation. Coastline curvature largely influences the timing and location of precipitation. Land breezes by themselves do not significantly impact subsequent precipitation, but they can have an influence on the location and intensity of precipitation in concert with coastline curvature. The physical mechanisms for modulating the timing, location, and intensity of precipitation by these factors are discussed below. 


\section{b. The role of soil moisture}

The initial distribution of soil moisture has a direct impact on the timing, location, and intensity of subsequent precipitation. In the simulations with variable initial soil moisture, heavy precipitation occurs in regions with wet soil (Figures 4 and 7). The highest peak accumulations occur in the simulations with variable initial soil moisture. Furthermore, the largest peak rain rates occur 1-2 hours later in the simulations with variable initial soil moisture than in the simulations with average soil moisture.

Two possible causes for this interaction between soil moisture distribution and precipitation are mesoscale circulations induced by soil moisture gradients (e.g., Ookouchi et al., 1984; Yan and Anthes, 1988; Lynn et al., 1998) and increased moisture in the convective boundary layer (Crook, 1996). There is no evidence of strong soil moisture-induced mesoscale circulations in our simulations. Figure 9 shows potential temperature and horizontal winds at 80 meters above the surface at 11 LST for simulations SAA and SVA. The horizontally averaged wind has been removed to delineate perturbations associated with mesoscale circulations. The sea breeze is well developed along both coasts in both simulations, while the peninsula interior is marked by small-scale perturbations associated with horizontal convective rolls. The major difference between SAA and SVA is reduced winds in the boundary layer in cool (wet) regions. For example, the sea breeze circulation is significantly weaker at $x=290$ $\mathrm{km}, y=60 \mathrm{~km}$ and at $x=120 \mathrm{~km}, y=260 \mathrm{~km}$ in simulation SVA than in SAA. At $80-\mathrm{m}$ altitude, soil moisture-induced mesoscale circulations would be characterized by flow from cool (wet) regions to warm (dry) regions. These circulations are not evident in Figure 9. 
Thus, large values of soil moisture weaken the sea breeze circulation by reducing the temperature contrast between land and ocean, but gradients in soil moisture do not produce a large enough temperature contrast to generate significant circulations between wet and dry soil.

The convective boundary layer is significantly moistened over regions with wet soil. Figure 10 shows vertical slices of water vapor perturbation (total water vapor mixing ratio minus the horizontally averaged water vapor mixing ratio) below $1 \mathrm{~km}$ altitude at $y=273$ $\mathrm{km}$ for simulations SAA and SVA. The location at $y=273 \mathrm{~km}$ corresponds to large values of soil moisture in SVA (Figure 4). At 10 LST, the boundary layer over the peninsula in control simulation SAA shows water vapor perturbations $\sim 0.1-0.5 \mathrm{~g} \mathrm{~kg}^{-1}$ (Figure 10). In contrast, the boundary over wet soil in simulation SVA shows water vapor perturbations $\sim$ $0.5-1.5 \mathrm{~g} \mathrm{~kg}^{-1}$. Variations of boundary layer moisture of $1 \mathrm{~g} \mathrm{~kg}^{-1}$ can help initiate moist convection in situations where deep moist convection is otherwise dormant (Crook, 1996). The convectively available potential energy (CAPE), averaged over the peninsula at $y=273$ $\mathrm{km}$, is $17 \%$ larger in simulation SVA than in SAA. In addition, CAPE over wet soil ( $y=273$ $\mathrm{km})$ is $14 \%$ larger than CAPE over dry soil $(y=160 \mathrm{~km})$ in simulation SVA. The lifting condensation level (LCL) is also lower over wet soil in simulation SVA (941 $\mathrm{mb}$ at $y=273$ $\mathrm{km}$ (wet soil) vs. $907 \mathrm{mb}$ at $y=160 \mathrm{~km}$ (dry soil)). Thus, variations in soil moisture produce greater convective instability and a lower cloud base over regions with wet soil. Subsequent heavy precipitation falls near or downwind of these regions. 


\section{c. The role of coastline curvature}

Coastline curvature influences the timing and location of heavy precipitation in our simulations, but it has little impact on the intensity of precipitation (except when coupled with heterogeneous initial conditions for wind (land breeze) as discussed in more detail below). Moderate to heavy rainfall, as determined by peak rain rates (Figure 8), occurs roughly 1 hour sooner in simulations with curved coastlines. The largest rainfall amounts are clustered along the east coast near Cape Canaveral $(x=310 \mathrm{~km}, y=170 \mathrm{~km})$ in simulations with curved coastlines, a distinctly different distribution of rainfall compared to simulations with straight coastlines (Figure 7). Indeed, in a qualitative sense, simulations with curved coastlines have rainfall distributions that most closely agree with the observed distribution (Figure 3).

It is well established that coastline curvature affects sea breeze convergence (e.g., McPherson, 1970; Pielke, 1974). Strong convergence occurs for coastlines with convex curvature while divergence occurs for concave coastlines. Vertical velocities are therefore larger inland of convex coastlines, and clouds preferentially develop at these locations (Pielke, 1974; Simpson et al., 1980). This mechanism occurs in our simulations with curved coastlines. Figure 11 indicates regions of convergence at $10 \mathrm{LST}$ in the lowest $440 \mathrm{~m}$ of the atmosphere for simulations SAA and CAA. Stronger convergence occurs in simulation CAA, with the largest values found inland of convex coastlines (e.g., Tampa Bay peninsulas on the west coast and Cape Canaveral on the east coast). Low-level divergence occurs inland of concave coastlines (note strong divergence near Tampa Bay). By comparison, simulation SAA exhibits rela- 
tively weak convergence at $10 \mathrm{LST}$. Earlier low-level convergence due to convex coastlines accounts for earlier rainfall in the curved coastline simulations. Furthermore, the heaviest rainfall accumulations on the east coast roughly coincide with regions of strong convergence in the late morning.

\section{d. The role of initial land breezes}

For the most part, simulations with initially variable horizontal winds (land breezes) do not show significant changes in the timing, intensity, or location of precipitation. It was believed prior to these simulations that the presence of land breeze circulations in our model (as opposed to horizontally homogeneous initial winds) could result in differences in the timing and intensity of low-level convergence and precipitation. Little difference occurs in low-level convergence prior to convective initiation between simulations SAA and SAV (not shown). As described below, land breezes have a significant role in precipitation processes only when coupled with other factors.

\section{e. Nonlinear interactions}

Much of the impact on the timing, location, and intensity of precipitation (Table II) can be attributed to a single factor (e.g., soil moisture or coastline curvature). For example, the location of heavy precipitation in simulations SVA and SVV coincides with initially wet soil. Likewise, timing and location changes in simulations with coastline curvature (CAA, CVA, $\mathrm{CAV}$, and CVV) can be attributed to earlier low-level convergence near convex coastlines. 
However, nonlinear interactions between the three factors (soil moisture, coastline curvature, and land breezes) do account for some of the differences among the simulations. Perhaps the most dramatic example of nonlinear interaction is seen in peak rain rates (Figure 8). Simulation CAV (curvature and land breeze) exhibits a maximum peak rain rate over $5 \mathrm{~mm} \mathrm{hr}^{-1}$ larger than simulations CAA (curvature only) and SAV (land breeze only) alone. Simulation CVV (all three factors present) shows similar behavior to CAV except that the maximum peak rain rate is delayed by 2 hours. For these cases, two or three factors act nonlinearly to enhance precipitation processes.

Coastline curvature and soil moisture can also mitigate the effects of each other. The preferred location of heavy precipitation in simulations with curved coastlines is near convex coastlines, while the preferred location in simulations with variable soil moisture is near wet soil. Because the distribution of soil moisture on this day places wet soil $50-100 \mathrm{~km}$ north of the convex coastline (Figure 4), the two effects compete for the preferred location. The net result is smaller rainfall accumulations (Figure 7) over wet soil and near Cape Canaveral for simulation CVA (curvature and soil moisture) compared to simulations SVA (soil moisture only) and CAA (curvature only).

\section{Discussion}

Sea breezes are primarily responsible for convective initiation and subsequent precipitation over central Florida on this day. Indeed, our control simulation representative of average sea breeze conditions reproduces the diurnal evolution and general distribution of precipitation 
over the peninsula. However, additional factors can modulate the timing, intensity, and location of sea-breeze initiated precipitation. Table II summarizes the impact of soil moisture, coastline curvature, and land breezes on precipitation in our simulations. The initial soil moisture distribution influences the timing, intensity, and location of precipitation. Coastline curvature primarily affects the timing and location of rainfall, but it can also influence the intensity of precipitation when coupled with early morning land breezes.

Our model results confirm previous Florida simulations (e.g., Pielke, 1974; Simpson et al., 1980; Boybeyi and Raman, 1992) regarding the relationship of coastline curvature, lowlevel convergence, and cloud development. Our simulations provide strong evidence on the impact of coastline curvature by comparing simulations with straight coastlines and curved coastlines, an approach not considered in previous work. Simulations with curved coastlines qualitatively agree most closely with the observed location of heavy precipitation. These results suggest that coastline curvature may have the strongest influence on determining the rainfall locations. Convex coastlines have long been known as preferred locations for cloud formation (Pielke, 1974; Simpson et al., 1980; Boybeyi and Raman, 1992).

However, soil moisture also has a dramatic impact on the spatial distribution of precipitation. Indeed, coastline curvature and soil moisture compete against one another in simulation CVA to reduce peak rainfall accumulations. The initial distribution of soil moisture in our model is determined from precipitation measurements over the previous 6 days. Numerous small lakes and rivers in central Florida are neglected in our simulations. For example, the Indian River in the Cape Canaveral area often exhibits a river breeze circu- 
lation that interacts with the east coast sea breeze front (Rao et al., 1999). Inclusion of inland water bodies in our model would increase the "effective" soil moisture in east-central Florida. Thus, coastline curvature and soil moisture could act together in concert to further enhance precipitation near Cape Canaveral.

Compared to previous Florida simulations, our simulations provide an alternative view regarding the role of soil moisture. Xu et al. (1996) find that their wet soil simulation produces peak accumulated rainfall amounts less than in their dry soil simulation, implying that large values of soil moisture inhibit sea-breeze initiated precipitation. Our results suggest the opposite: soil moisture can promote convective development and subsequent precipitation. Soil moisture in our simulations acts an atmospheric moisture source, thereby increasing the CAPE and preferentially producing heavy rainfall over previously wet soil. A positive feedback mechanism may begin in which rainfall increases soil moisture which, in turn, promotes heavy rainfall in the same location. A key prerequisite for this positive feedback mechanism is a moist atmosphere. In our simulations, relative humidities of roughly $80-85 \%$ exist initially at $0600 \mathrm{LST}$ from the surface to $500 \mathrm{mb}$. The atmosphere is primed to convect under these moist conditions, and soil moisture gives the atmosphere a boost toward convective instability. If the atmosphere were relatively dry, large values of soil moisture would reduce the sensible heat flux to the atmosphere and would likely inhibit convective development. In fact, the atmospheric sounding used in Xu et al. (1996) is significantly drier than the sounding used here. The ability of soil moisture to influence convective development may be intimately tied to existing atmospheric moisture conditions (e.g., Rabin et al., 1990). 
Strong mesoscale circulations induced by soil moisture gradients are not evident in our simulations. Such circulations are characteristically found in numerical simulations with relatively weak environmental winds and step-wise soil moisture gradients (e.g., Yan and Anthes, 1988; Avissar and Liu, 1996; Lynn et al., 1998). Although initial low-level wind shear in our simulations ( $4.3 \mathrm{~m} \mathrm{~s}^{-1}$ from the surface to $1 \mathrm{~km}$ altitude) is relatively weak, environmental winds in the boundary layer of roughly $3-5 \mathrm{~m} \mathrm{~s}^{-1}$ may be large enough to disrupt mesoscale circulations induced by soil moisture. Furthermore, soil moisture gradients in our simulations are much smoother than step-wise gradients in previous idealized simulations, perhaps further inhibiting development of strong mesoscale circulations.

Although the model performs quite well in capturing sea breeze development, cloud formation, cloud propagation, and convective precipitation, it does a lesser job of producing a broad stratiform region behind the line of convective cells. As a result, the area-averaged rain rates in all simulations (not shown) are roughly $30-50 \%$ of observed area-averaged rain rates. Additional simulations were performed to test the sensitivity of squall line development on heterogeneous initial conditions for atmospheric moisture, on increased mid-level moisture, and on higher grid resolution $(1.6-\mathrm{km}$ resolution in the $\mathrm{x}$-direction and $2.5-\mathrm{km}$ resolution in the $\mathrm{y}$-direction). None of these additional simulations produced larger area-averaged rain rates. One possible reason for the development of a weak squall line in our simulations is the presence of weak low-level shear. Cloud models often have difficulty producing strong squall lines under weakly sheared conditions (e.g., Rotunno et al., 1988). In addition, squall line simulations without artificial cool pool initiation may require very fine horizontal grid 
resolution of $1-\mathrm{km}$ or less to adequately capture cloud mergers (Tao and Simpson, 1989). Improvements in cloud microphysics from a 3 -ice scheme to a 4-ice scheme (Ferrier et al., 1995) may result in better simulation of trailing stratiform precipitation. The absence of Lake Okeechobee in our simulations may also contribute to reduced area-averaged rainfall. As seen in Figures 2 and 3, Lake Okeechobee influences cloud development and precipitation over a broad region north and west of the lake. Finally, synoptic scale forcing may have played a role in squall line development over central Florida on 27 July 1991. The southernmost portion of a $700 \mathrm{mb}$ westerly trough extended into central Florida at $0700 \mathrm{LST}$. This trough produced weak mid-level divergence over the Florida peninsula, perhaps enhancing uplift and later squall line formation (Halverson et al., 1996).

The sensitivity of our simulations to initial soil moisture and winds has implications for severe storm forecasting. Initial conditions with high spatial resolution are required for good forecasts. Dense sounding networks augmented by satellite wind estimates and regional scale model output may be used for improved wind initial conditions (e.g., Velden et al., 1997). Microwave satellite estimates of soil moisture can provide wide spatial coverage at moderately high resolution $(\sim 30 \mathrm{~km})$ (Lakshmi et al., 1997). In addition, high resolution estimates of precipitation from rain gauges, radar, and satellites (e.g., Tropical Rainfall Measuring Mission (TRMM) and Global Precipitation Mission (GPM)) can be input into offline landsurface models such as PLACE to provide high resolution soil moisture initial conditions for fully coupled atmosphere/land-surface models. This method offers the advantage of utilizing consistent physics parameterizations for initial conditions and for model forecasts. 


\section{Summary}

Eight idealized numerical simulations have been performed with a coupled atmosphere/landsurface model (GCE-PLACE) to test the effects of soil moisture, coastline curvature, and land breezes on sea-breeze initiated precipitation. The 27 July 1991 squall line over central Florida observed during CaPE is considered. The key results are summarized in Table II and below:

1. The distribution of initial soil moisture influences the timing, location, and intensity of precipitation. The heaviest precipitation preferentially occurs over wet soil. Soil moisture acts as an atmospheric moisture source and increases the convectively available potential energy. There is no evidence of strong mesoscale circulations induced by soil moisture gradients in our simulations.

2. Coastline curvature impacts the timing and location of precipitation by inducing earlier low-level convergence near regions with convex curvature. The heaviest precipitation occurs inland of convex coastlines.

3. Early morning land breeze circulations have little impact on the timing, intensity, and location of precipitation except when coupled with curved coastlines. Nonlinear interaction between coastline curvature and land breeze circulations produces peak rain rates over $20 \%$ larger than in simulations without both effects.

4. The roles of coastline curvature and soil moisture are comparable in magnitude. Because the largest values of soil moisture on this day are not spatially correlated with convex 
coastlines, the two factors compete against one another and thus tend to reduce peak rainfall amounts.

Acknowledgments. This paper greatly benefited from useful discussions with Jeffrey Halverson, Brad Ferrier, Peter Wetzel, Stephen Lang, and Daniel Johnson. This work is supported by the NASA Headquarters Physical Climate Program. We thank Dr. R. Kakar (HQ) for his support. 


\section{References}

Atkins, N. T. and R. M. Wakimoto, 1997: Influence of the synoptic-scale flow on sea breezes observed during CaPE. Mon. Wea. Rev., 125, 2112-2130.

Avissar, R. and Y.-Q. Liu, 1996: Three-dimensional numerical study of shallow convective clouds and precipitation induced by land surface forcing. J. Geophys. Res., 101, 74997518.

Blanchard, D. O. and R. E. Lopez, 1985: Spatial patterns of convection in south Florida. Mon. Wea. Rev., 113, 1282-1299.

Boybeyi, Z. and S. Raman, 1992: A three-dimensional numerical sensitivity study of convection over the Florida peninsula. Bound. Layer Meteor., 60, 325-359.

Businger, J. A., J. C. Wyngaard, Y. Izumi, and E. F. Bradley, 1971: Flux-profile relationships in the atmospheric surface layer. J. Atmos. Sci., 28, 181-189.

Byers, H. R. and H. R. Rodebush, 1948: Causes of thunderstorms of the Florida peninsula. J. Meteor., 5, 275-280.

Chen, T. H., A. Henderson-Sellers, P. C. D. Milly, A. J. Pitman, A. C. M. Beljaars, J. Polcher, F. Abramopoulos, A. Boone, S. Chang, F. Chen, Y. Dai, C. E. Desborough, R. E. Dickinson, L. Dumenil, M. Ek, J. R. Garratt, N. Gedney, Y. M. Gusev, J. Kim, R. Koster, E. A. Kowalczyk, K. Laval, J. Lean, D. Lettenmaier, X. Liang, J. F. Mahfouf, H. T. Mengelkamp, K. Mitchell, O. N. Nasonova, J. Noilhan, A. Robock, C. Rosenzweig, J. Schaake, 
C. A. Schlosser, J. P. Schulz, Y. Shao, A. B. Shmakin, D. L. Verseghy, P. Wetzel, E. F. Wood, Y. Xue, Z. L. Yang, and Q. Zeng, 1997: Cabauw experimental results from the project for intercomparison of land-surface parameterization schemes. J. Climate, 10, $1194-1215$.

Crook, N. A., 1996: Sensitivity of moist convection forced by boundary layer processes to low-level thermodynamic fields. Mon. Wea. Rev., 124, 1767-1785.

Fankhauser, J. C., N. A. Crook, J. Tuttle, L. J. Miller, and C. G. Wade, 1995: Initiation of deep convection along boundary layer convergence lines in a semitropical environment. Mon. Wea. Rev., 123, 291-313.

Ferrier, B. S., W.-K. Tao, and J. Simpson, 1995: A double-moment multiple-phase fourclass bulk ice scheme. Part II: Simulations of convective storms in different large-scale environments and comparisons with other bulk parameterizations. J. Atmos. Sci., 52, $1001-1033$.

Halverson, J., M. Garstang, J. Scala, and W.-K. Tao, 1996: Water and energy budgets of a Florida mesoscale convective system: A combined observational and modeling study. Mon. Wea. Rev., 124, 1161-1180.

Kingsmill, D. E., 1995: Convection initiation associated with a sea-breeze front, a gust front, and their collision. Mon. Wea. Rev., 123, 2913-2933. 
Lakshmi, V., E. F. Wood, and B. J. Choudhury, 1997: Evaluation of Special Sensor Microwave/Imager satellite data for regional soil moisture estimation over the Red River basin. J. Appl. Meteor., 36, 1309-1328.

Lin, Y.-L., R. D. Rarley, and H. D. Orville, 1983: Bulk parameterization of the snow field in a cloud model. J. Climate Appl. Meteor., 22, 1065-1092.

Lynn, B. H., W.-K. Tao, and P. Wetzel, 1998: A study of landscape generated deep moist convection. Mon. Wea. Rev., 126, 928-942.

McPherson, R. D., 1970: A numerical study of the effect of a coastal irregularity on the sea breeze. J. Appl. Meteo., 9, 767-777.

Meeson, B. W., F. E. Corprew, J. M. P. McManus, D. M. Meyers, J. W. Closs, K.-J. Sun, D. J. Sunday, and P. J. Sellers, 1995: ISLSCP initiative I: Global data sets for landatmosphere models, 1987-1988. NASA, 1-5, Published on CD.

Moncrieff, M., S. K. Krueger, D. Gregory, J. L. Redelsperger, and others., 1997: GEWEX Cloud System Study (GCSS) Working Group 4: Precipitating convective cloud systems. Bulletin of the American Meteorological Society, 78, 831-845.

Nair, U. S., M. R. Hjelmfelt, and R. A. Pielke Sr., 1997: Numerical simulation of the 9-10 June 1972 Black Hills storm using CSU RAMS. Mon. Wea. Rev., 125, 1753-1766. 
Nicholls, M. E., R. Pielke, and W. Cotton, 1991: A two-dimensional numerical investigation of the interaction between sea breezes and deep convection over the Florida pennisula. Mon. Wea. Rev., 119, 298-323.

Ookouchi, Y., M. Segal, R. C. Kessler, and R. A. Pielke, 1984: Evaluation of soil moisture effects on the generation and modification of mesoscale circulations. Mon. Wea. Rev., 112, $2281-2292$.

Pielke, R. A., 1974: A three-dimensional numerical model of the sea breezes over south Florida. Mon. Wea. Rev., 102, 115-139.

Rabin, R., S. Stadler, P. Wetzel, D. Stensrud, and M. Gregory, 1990: Observed effects of landscape variability on convective clouds. Bull. Amer. Meteor. Soc., 71, 272-280.

Rao, P. A., H. E. Fuelberg, and K. K. Droegemeier, 1999: High-resolution modeling of the Cape Canaveral area land-water circulations and associated features. Mon. Wea. Rev., 127, 1808-1821.

Rotunno, R., J. B. Klemp, and M. L. Weisman, 1988: A theory for strong, long-lived squall lines. J. Atmos. Sci., 45, 463-485.

Rutledge, S. A. and P. V. Hobbs, 1984: The mesoscale and microscale structure and organization of clouds and precipitation in midlatitude cyclones. Part XII: A diagnostic modeling study of precipitation development in narrow cold frontal rainbands. J. Atmos. Sci., 41, $2949-2972$. 
Simpson, J. and W.-K. Tao, 1993: Goddard Cumulus Ensemble Model. Part II: Applications for studying cloud precipitating processes and for NASA TRMM. Terr. Atmos. Oceanic Sci., 4, 73-116.

Simpson, J., N. E. Westcott, R. J. Clerman, and R. A. Pielke, 1980: On cumulus mergers. Arch. Met. Geophys. Biokl., 29, 1-40.

Tao, W. K. and J. Simpson, 1989: A further study of cumulus interactions and mergers: Three-dimensional simulations with trajectory analyses. J. Atmos. Sci., 46, 2974-3004.

Tao, W.-K. and J. Simpson, 1993: Goddard Cumulus Ensemble Model. Part I: Model description. Terr. Atmos. Oceanic Sci., 4, 35-72.

Ulanski, S. L. and M. Garstang, 1978: The role of surface divergence and vorticity in the life cycle of convective rainfall. I. Observation and analysis. J. Atmos. Sci., 35, 1047-1062.

Velden, C. S., C. M. Hayden, S. J. Nieman, W. P. Menzel, S. Wanzong, and J. S. Goerss, 1997: Upper-tropospheric winds derived from geostationary satellite water vapor observations. Bull. Amer. Meteor. Soc., 78, 173-195.

Weisman, M. L., W. C. Skamarock, and J. B. Klemp, 1997: The resolution dependence of explicitly modeled convective systems. Mon. Wea. Rev., 1215, 527-548.

Wetzel, P. and A. Boone, 1995: A parameterization for Land-Atmosphere- Cloud Exchange (PLACE): Documentation and testing of a detailed process model of the partly cloudy boundary layer over heterogeneous land. J. Climate, 8, 1810-1837. 
Wilson, J. W. and D. L. Megenhardt, 1997: Thunderstorm initiation, organization, and lifetime associated with Florida boundary layer convergence lines. Mon. Wea. Rev., 125, $1507-1525$.

Woodruff, S. D., S. J. Lubker, K. Wolter, S. J. Worley, and J. D. Elms, 1993: Comprehensive ocean-atmosphere data set (COADS) Release 1a: 1980-92. Earth Sys. Monitor, 4, 1-8.

Xu, L., S. Raman, R. V. Madala, and R. Hodur, 1996: A non-hydrostatic modeling study of surface moisture effects on mesoscale convection induced by sea breeze circulation. Meteor. Atmos. Phy., 58, 103-122.

Yan, H. and R. A. Anthes, 1988: The effect of variations in surface moisture on mesoscale circulations. Mon. Wea. Rev., 116, 192-208.

Zilitinkevich, S. S., 1975: Comments on a model for the dynamics of the inversion above a convective boundary layer. J. Atmos. Sci., 32, 991-992. 


\section{Figure Captions}

Figure 1 Average sounding from four sounding locations in central Florida (Tampa, Dunnellon, Daytona, and Fellsmere) on 27 July 1991, 0600 LST (1100 UTC).

Figure 2 GOES-7 1-km visible satellite images over central Florida on 27 July 1991 at a) 13:01 LST (18:01 UTC), b) 15:01 LST (20:01 UTC), and c) 17:01 LST (22:01 UTC).

Figure 3 Accumulated rainfall, 27 July 1991, 06-21 LST, from rain gauge measurements. Crosses indicate PAM site locations and diamonds indicate NOAA weather observing sites.

Figure 4 Initial root zone soil moisture derived from offline PLACE simulations for 27 July 1991, 0600 LST for a) straight coastline simulations with variable initial soil moisture (Cases SVA and SVV), and b) curved coastline simulation with variable initial soil moisture (Cases CVA and CVV). Cases SAA and SAV use the straight coastline configuration with horizontally averaged initial soil moisture, while Cases CAA and CAV uses the curved coastline configuration with average initial soil moisture.

Figure 5 Heterogeneous horizontal wind initial condition in the $2-4 \mathrm{~km}$ altitude layer for Cases SAV, SVV, CAV, and CVV. Arrows denote velocity direction and magnitude, and contours indicate wind speeds. Land breezes can be seen along 
both coasts.

Figure 6 Column integrated hydrometeors $\left(\mathrm{kg} \mathrm{m}^{-2}\right)$ for simulation CVV at a) 13 LST, b) 15 LST, and c) 17 LST.

Figure 7 Accumulated rainfall from 06 to 21 LST for simulations a) SAA, b) SVA, c) SAV, d) SVV, e) CAA, f) CVA, g) CAV, and h) CVV. See Table I for meaning of abbreviations.

Figure 8 Peak rain rates $\left(\mathrm{mm} \mathrm{hr}^{-1}\right)$ vs. local time for a) straight coastline simulations, and b) curved coastline simulations. Triangles indicate observed peak rain rates from rain gauge measurements.

Figure 9 Potential temperature $\theta$ (over land only) and perturbation horizontal winds at 80 meters height at 11 LST for a) simulation SAA and b) simulation SVA.

Figure 10 Water vapor mixing ratio perturbation at $y=273 \mathrm{~km}$ in the lowest 1 $\mathrm{km}$ at 10 LST for simulation a) SAA and b) SVA. The contour interval is $0.5 \mathrm{~g}$ $\mathrm{kg}^{-1}$. The convectively available potential energy (CAPE) averaged across the peninsula at $y=273 \mathrm{~km}$ is also shown.

Figure 11 Low-level convergence below $440 \mathrm{~m}$ altitude at 10 LST for simulation a) SAA, and b) CAA. Solid contour lines indicate convergence and dotted lines indicate divergence. The contour interval is $0.001 \mathrm{~s}^{-1}$. 
Table I: Model simulations.

\begin{tabular}{cccc}
\hline \hline & & $\begin{array}{c}\text { Soil Moisture } \\
\text { Case }\end{array}$ & $\begin{array}{c}\text { Wind } \\
\text { Coastline }\end{array}$ \\
Initial Condition & Initial Condition \\
\hline SAA & Straight & Average & Average \\
SVA & Straight & Variable & Average \\
SAV & Straight & Average & Variable \\
SVV & Straight & Variable & Variable \\
CAA & Curved & Average & Average \\
CVA & Curved & Variable & Average \\
CAV & Curved & Average & Variable \\
CVV & Curved & Variable & Variable \\
\hline
\end{tabular}


Table II: Summary of impact on precipitation by coastline curvature, soil moisture, and land breezes.

\begin{tabular}{lcccc}
\hline \hline & & & Intensity & $\begin{array}{c}\text { Intensity } \\
\text { Factor (Simulation) }\end{array}$ \\
\hline Control (SAA) & Timing & Location & (Rain Rate) & (Accumulation) \\
Soil Moisture (SVA) & - & - & - & - \\
Land Breeze (SAV) & $\mathrm{X}$ & $\mathrm{X}$ & - & $\mathrm{X}$ \\
Soil Moisture, Land Breeze (SVV) & $\mathrm{X}$ & $\mathrm{X}$ & - & - \\
Curved (CAA) & $\mathrm{X}$ & $\mathrm{X}$ & - & $\mathrm{X}$ \\
Curved, Soil Moisture (CVA) & $\mathrm{X}$ & $\mathrm{X}$ & - & - \\
Curved, Land Breeze (CAV) & $\mathrm{X}$ & $\mathrm{X}$ & $\mathrm{X}$ & - \\
Curved, Soil Moisture, & $\mathrm{X}$ & $\mathrm{X}$ & $\mathrm{X}$ & - \\
\multicolumn{1}{c}{ Land Breeze (CVV) } & & & & $\mathrm{X}$ \\
\hline
\end{tabular}




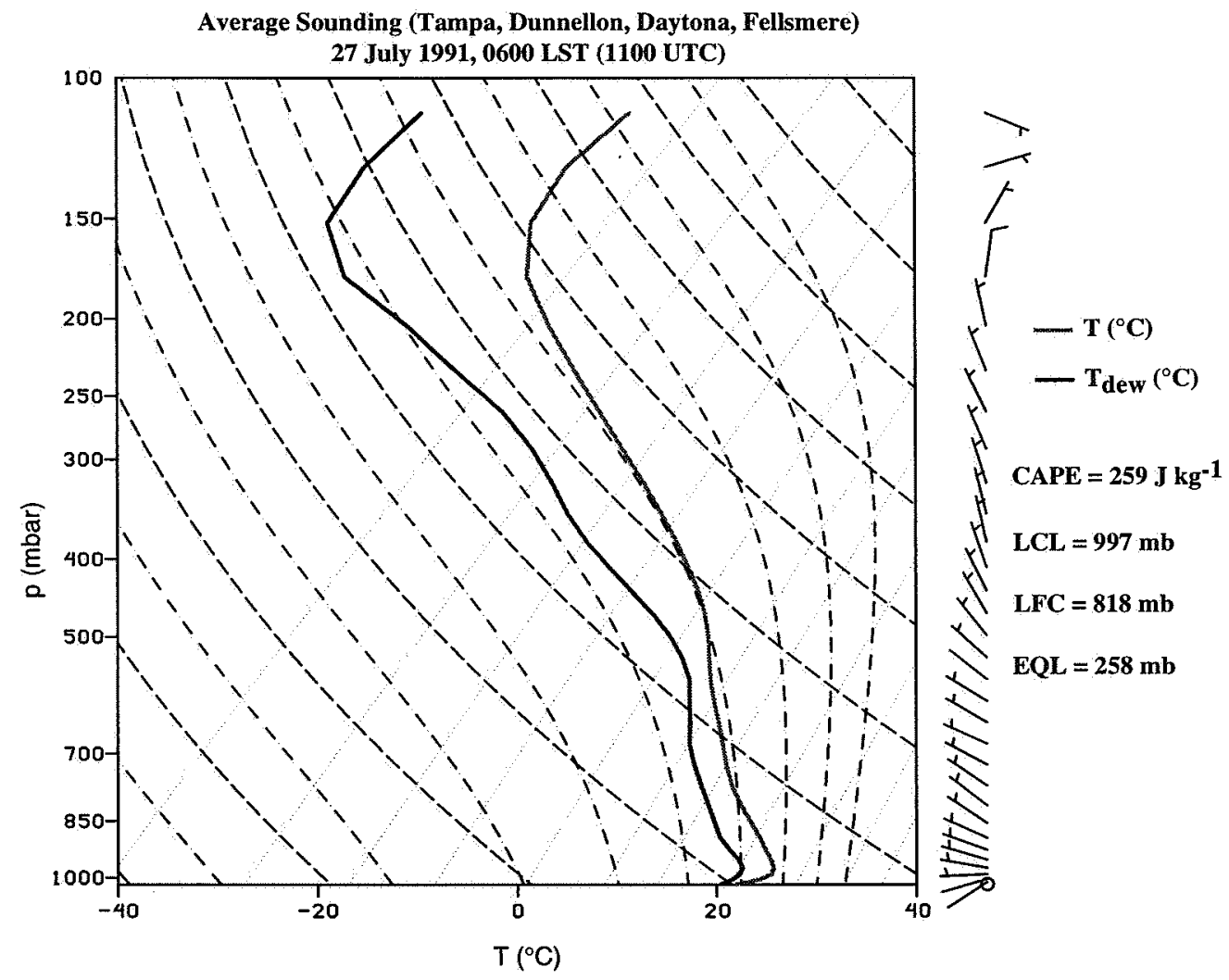

Figure 1: Average sounding from four sounding locations in central Florida (Tampa, Dunnellon, Daytona, and Fellsmere) on 27 July 1991, 0600 LST (1100 UTC). 

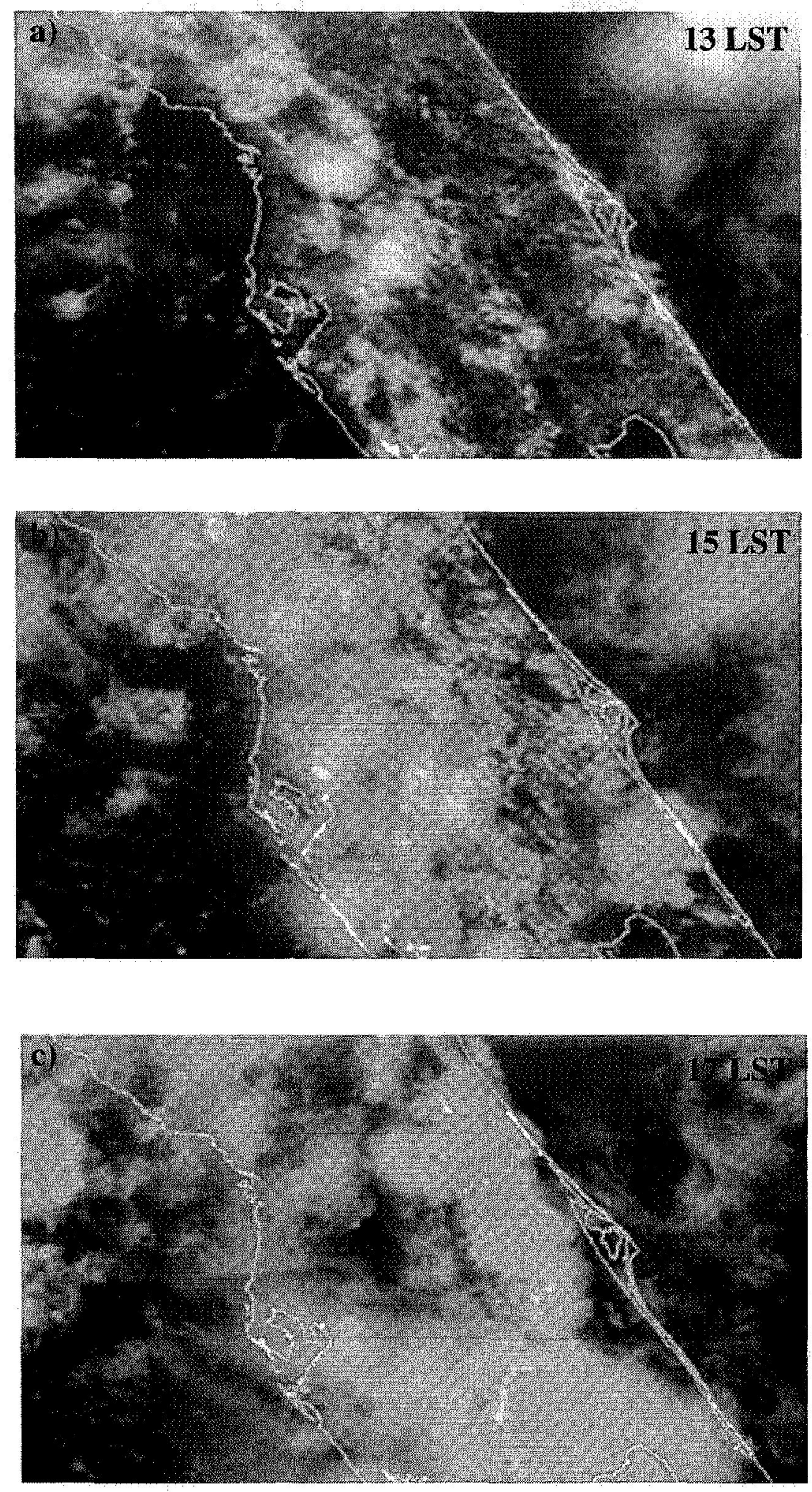

Figure 2: GOES-7 1-km visible satellite images over central Florida on 27 July 1991 at a) 13:01 LST (18:01 UTC), b) 15:01 LST (20:01 UTC), and c) 17:01 LST (22:01 UTC). 


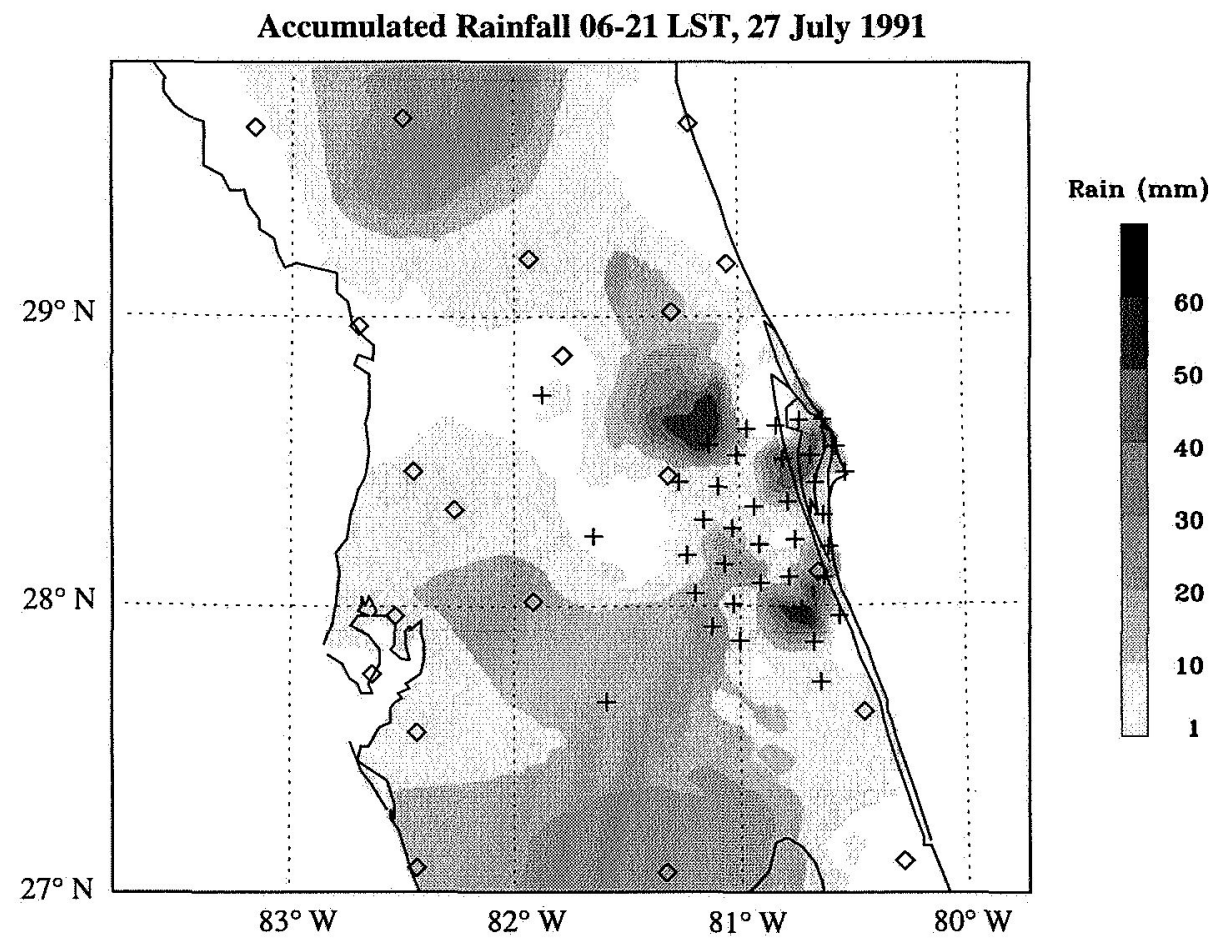

Figure 3: Accumulated rainfall, 27 July 1991, 06-21 LST, from rain gauge measurements. Crosses indicate PAM site locations and diamonds indicate NOAA weather observing sites. 


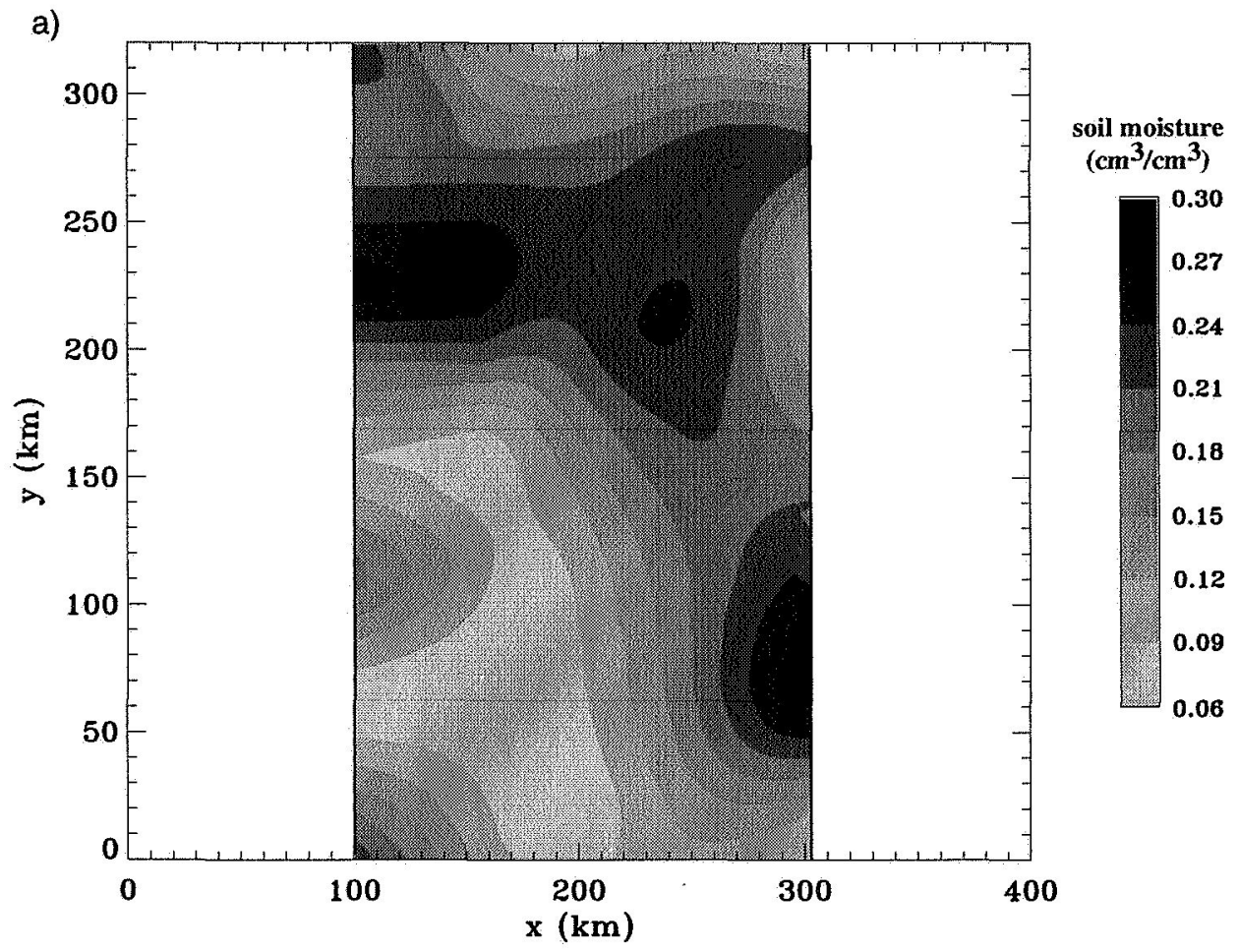

Figure 4: Initial root zone soil moisture derived from offline PLACE simulations for 27 July 1991, 0600 LST for a) straight coastline simulations with variable initial soil moisture (Cases SVA and SVV), and b) curved coastline simulations with variable initial soil moisture (Cases CVA and CVV). Cases SAA and SAV use the straight coastline configuration with horizontally averaged initial soil moisture, while Cases CAA and CAV uses the curved coastline configuration with average initial soil moisture. 


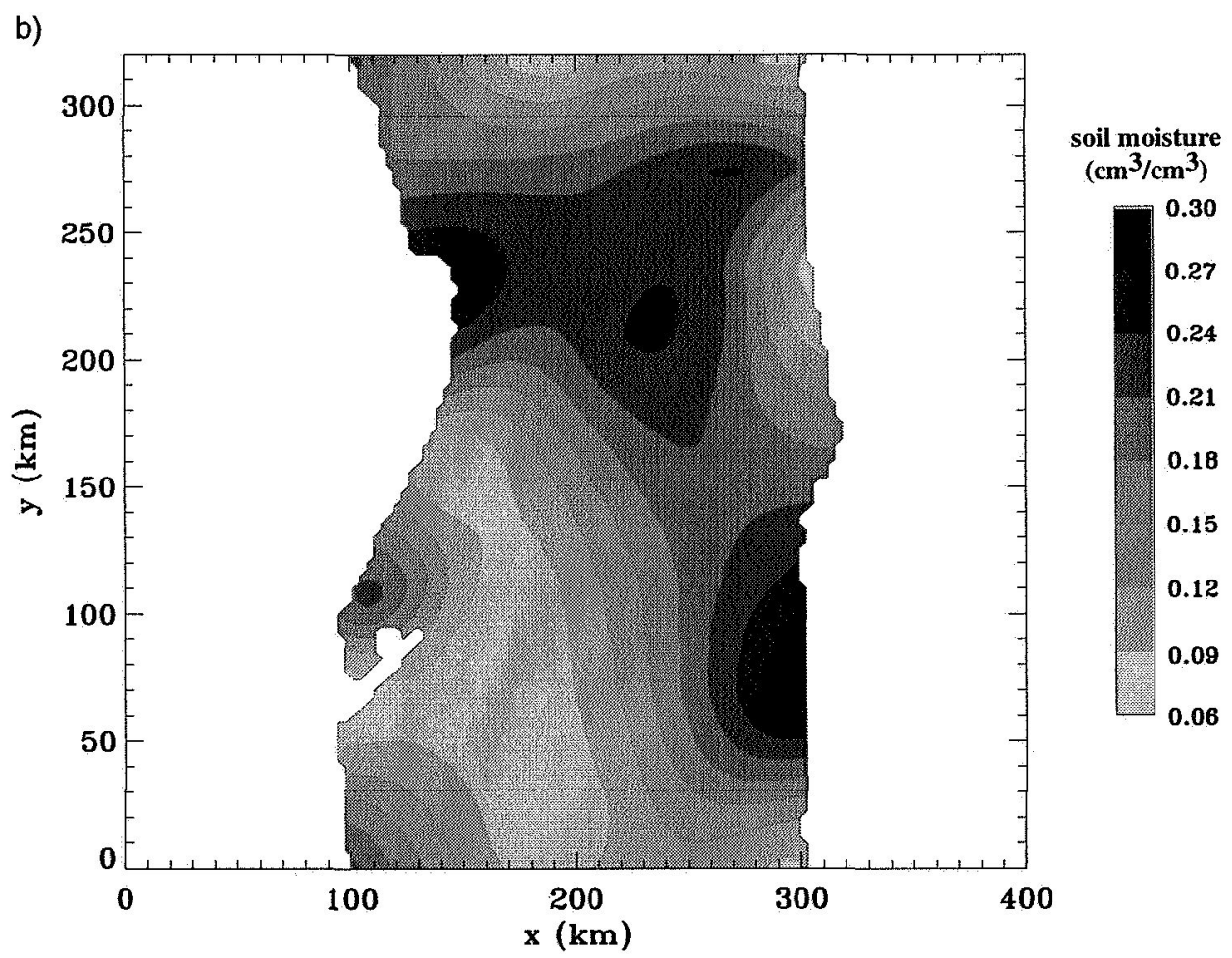

Figure 4: Continued. 


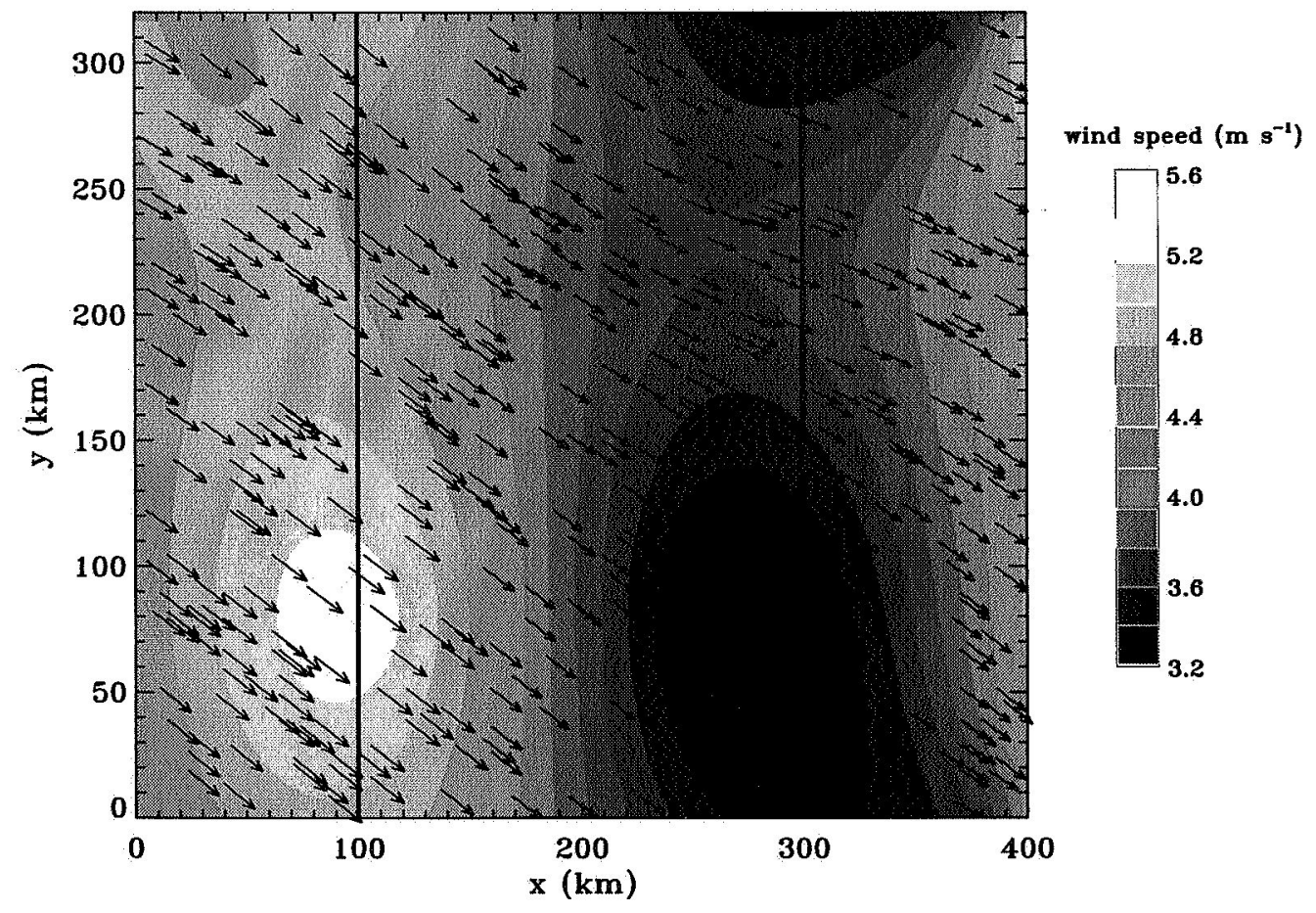

Figure 5: Heterogeneous horizontal wind initial condition in the $2-4 \mathrm{~km}$ altitude layer for Cases SAV, SVV, CAV, and CVV. Arrows denote velocity direction and magnitude, and contours indicate wind speeds. Land breezes can be seen along both coasts. 


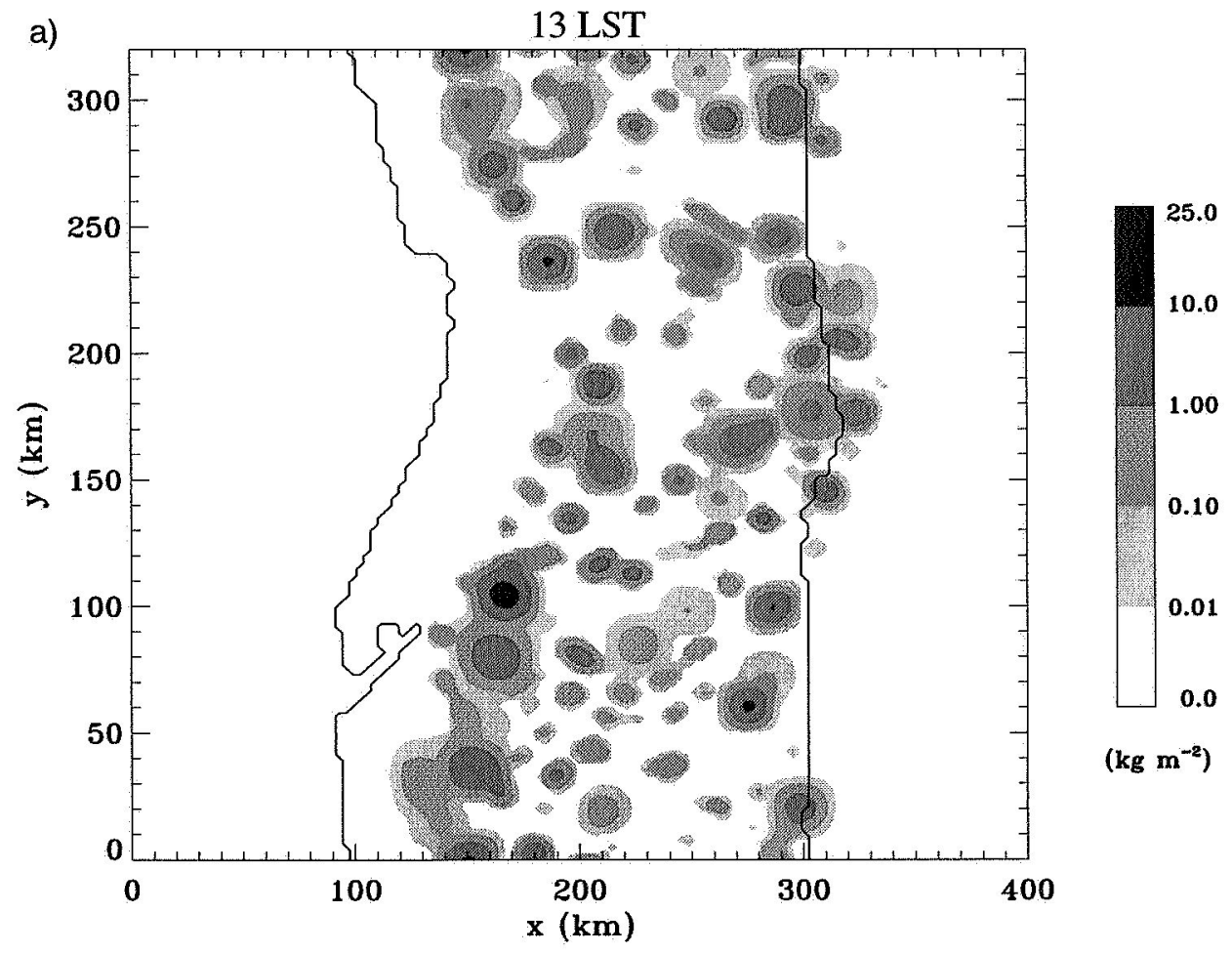

Figure 6: Column integrated hydrometeors $\left(\mathrm{kg} \mathrm{m}^{-2}\right)$ for simulation CVV at a) 13 LST, b) $15 \mathrm{LST}$, and c) 17 LST. 


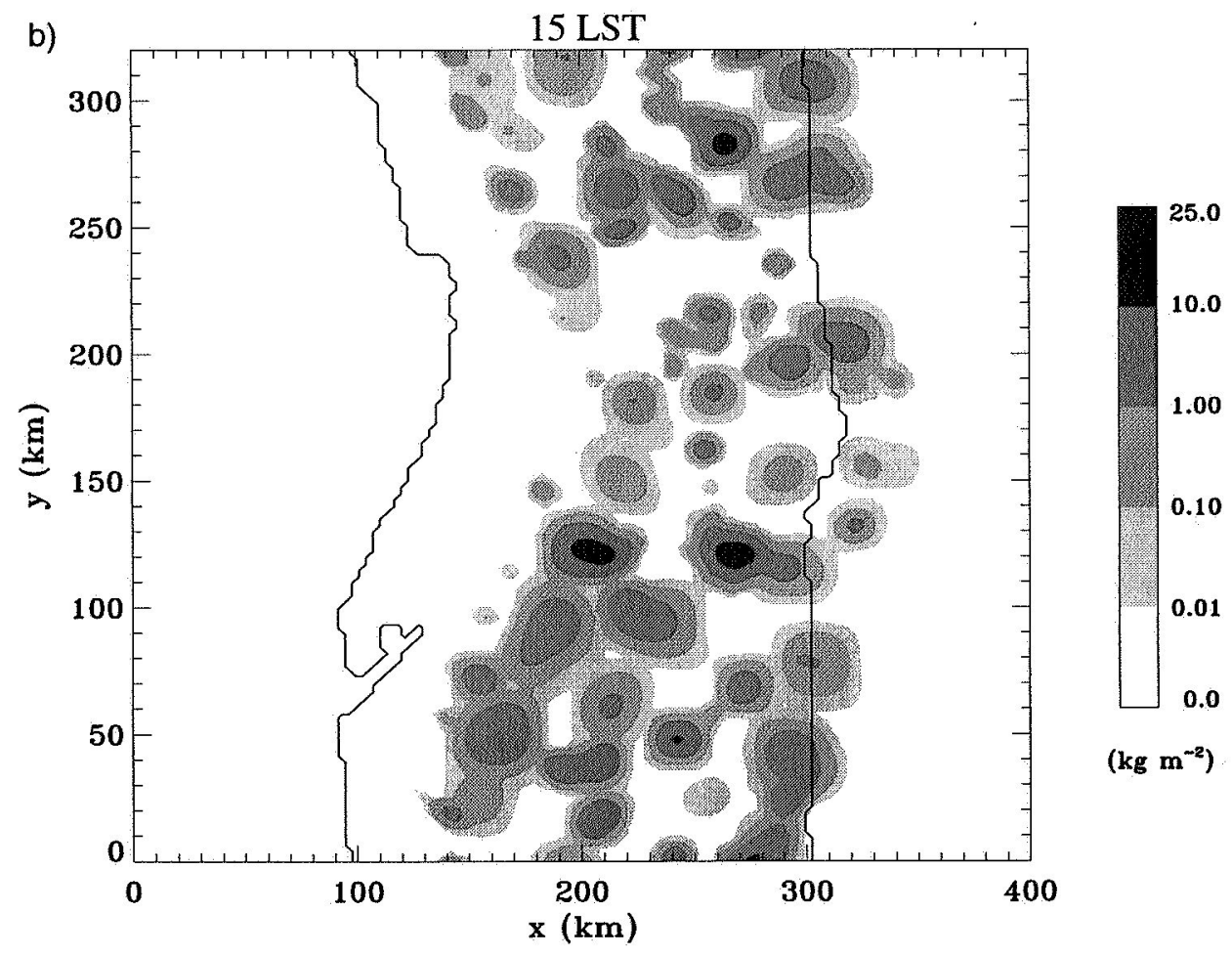

Figure 6: Continued. 


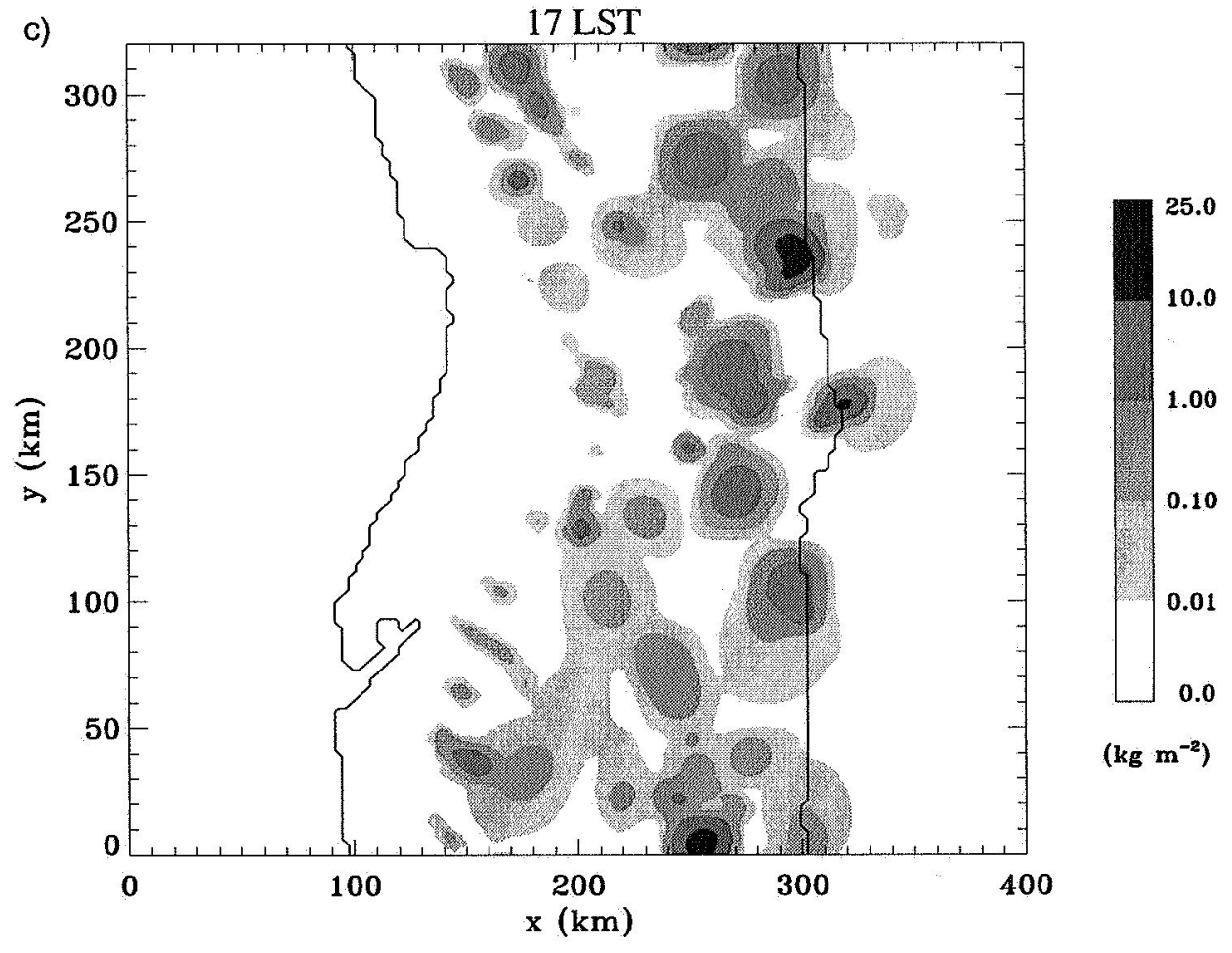

Figure 6: Continued. 


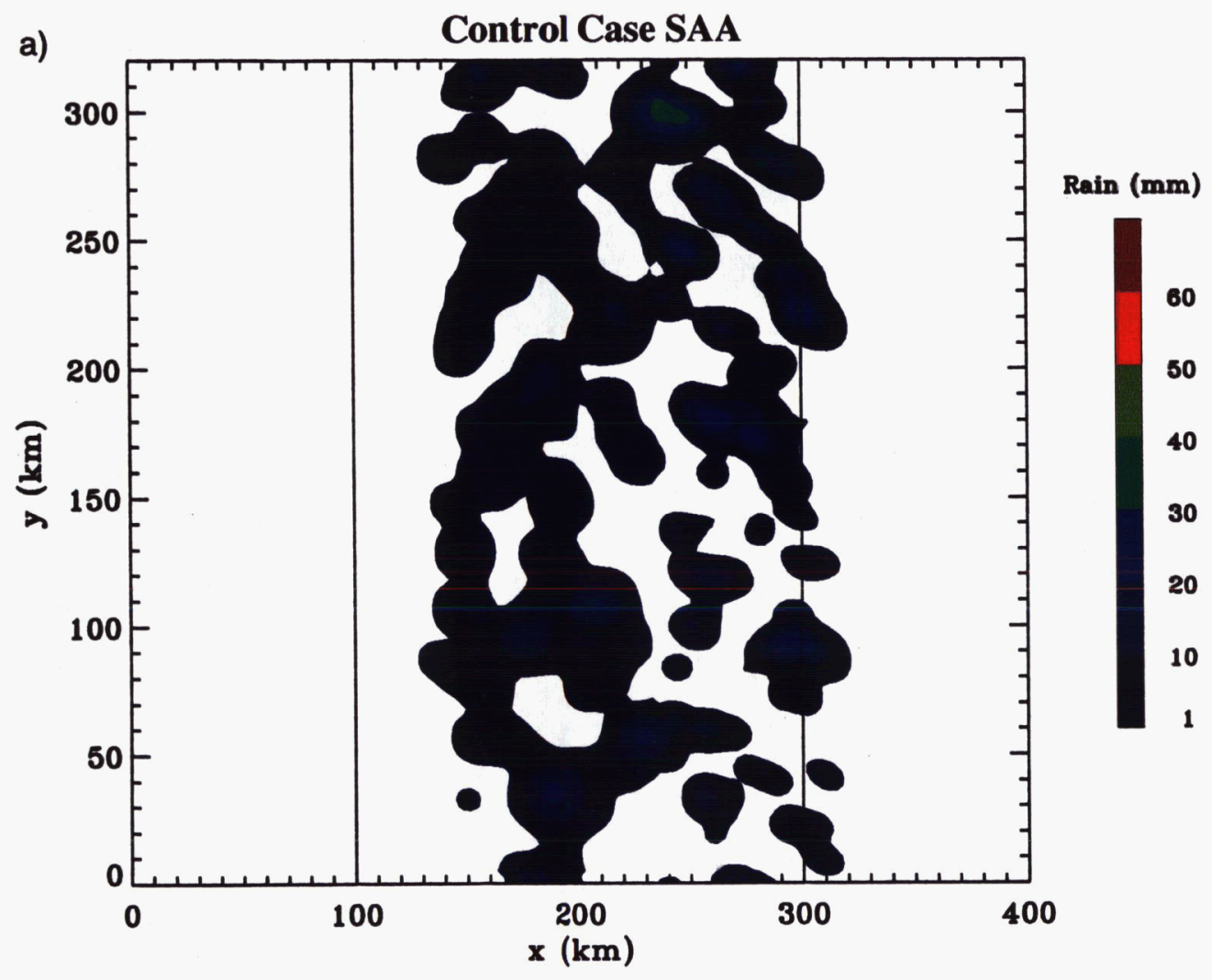

Figure 7: Accumulated rainfall from 06 to 21 LST for simulations a) SAA, b) SVA, c) SAV, d) SVV, e) CAA, f) CVA, g) CAV, and h) CVV. See Table I for meaning of abbreviations. 


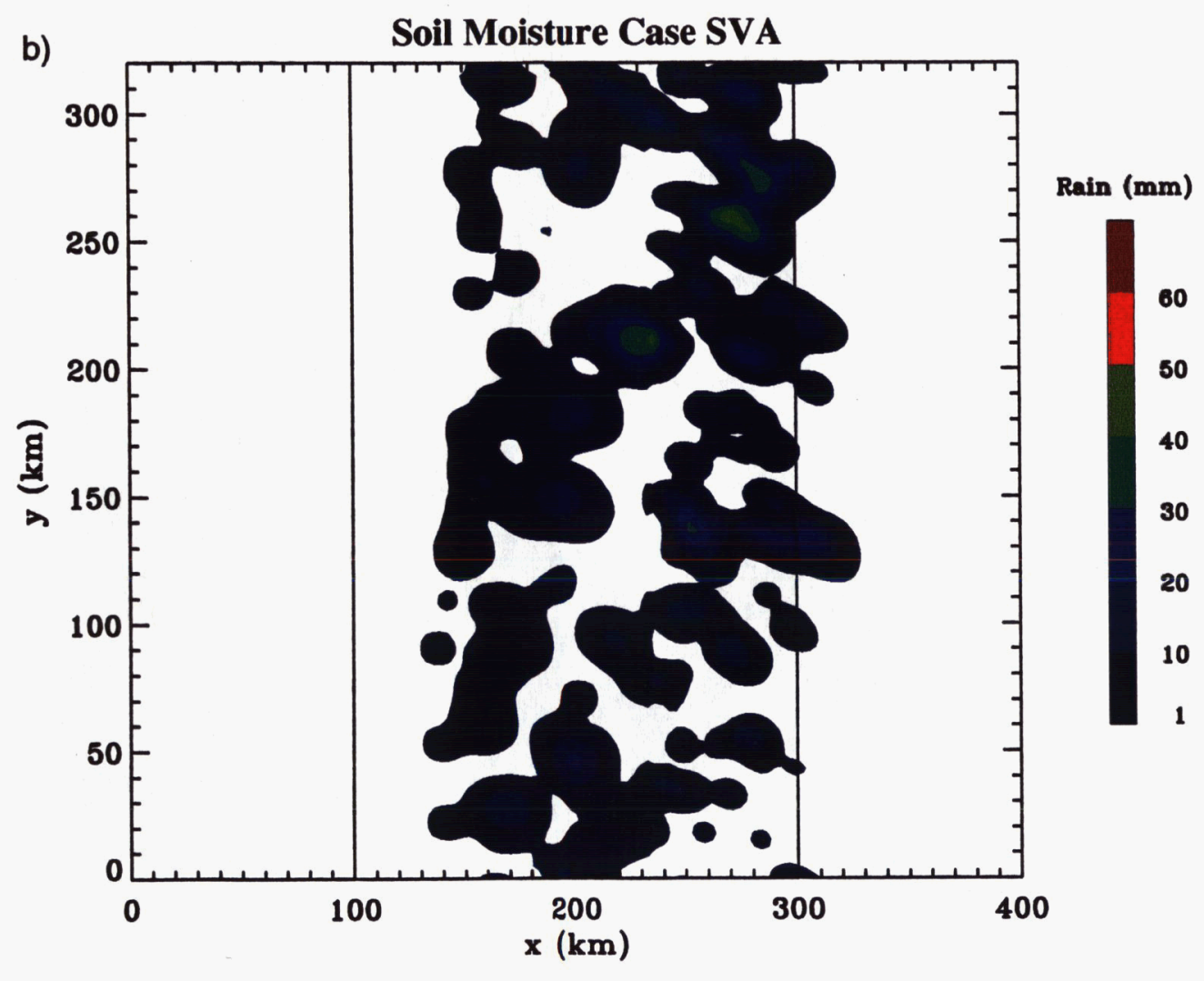

Figure 7: Continued. 


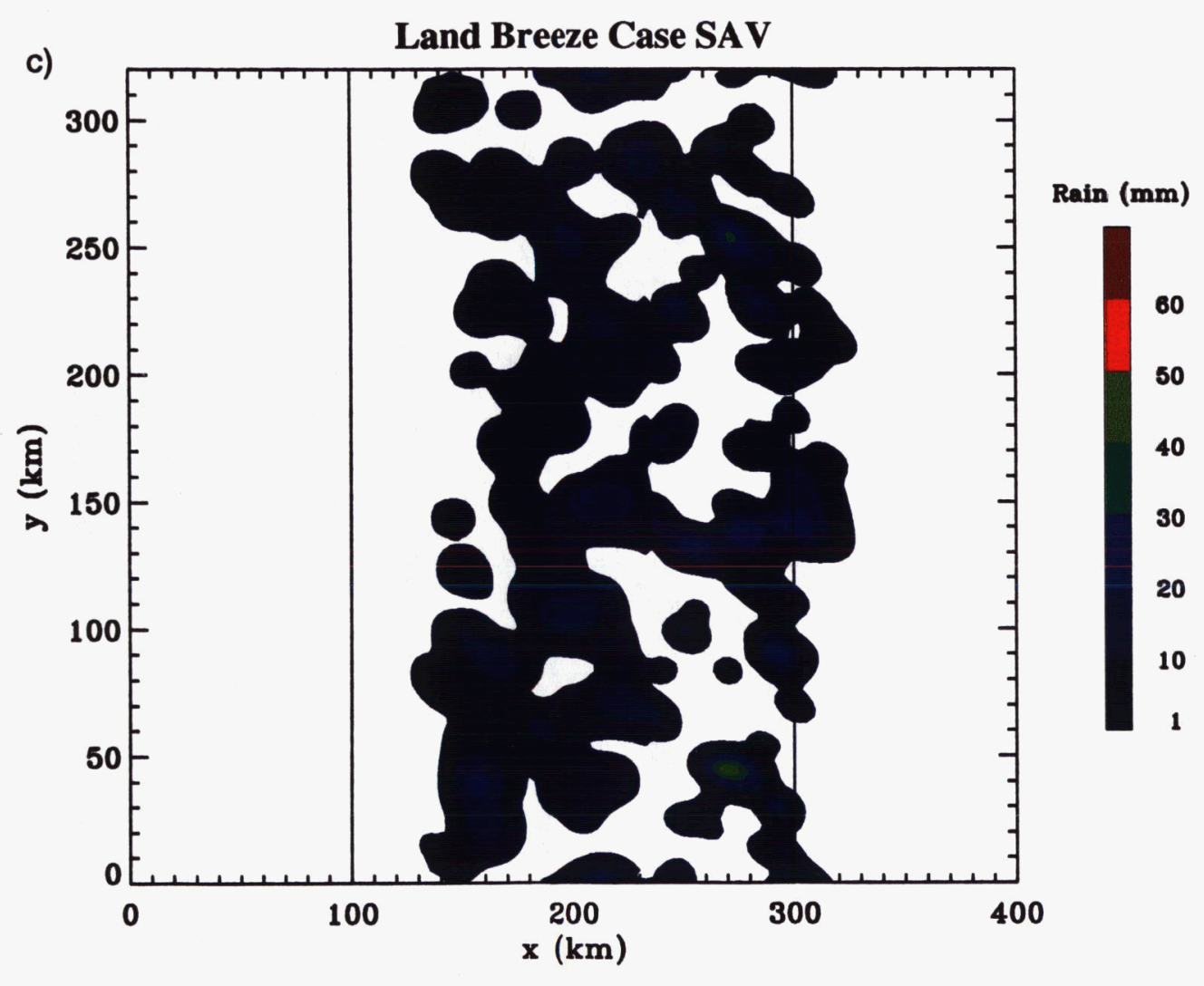

Figure 7: Continued. 


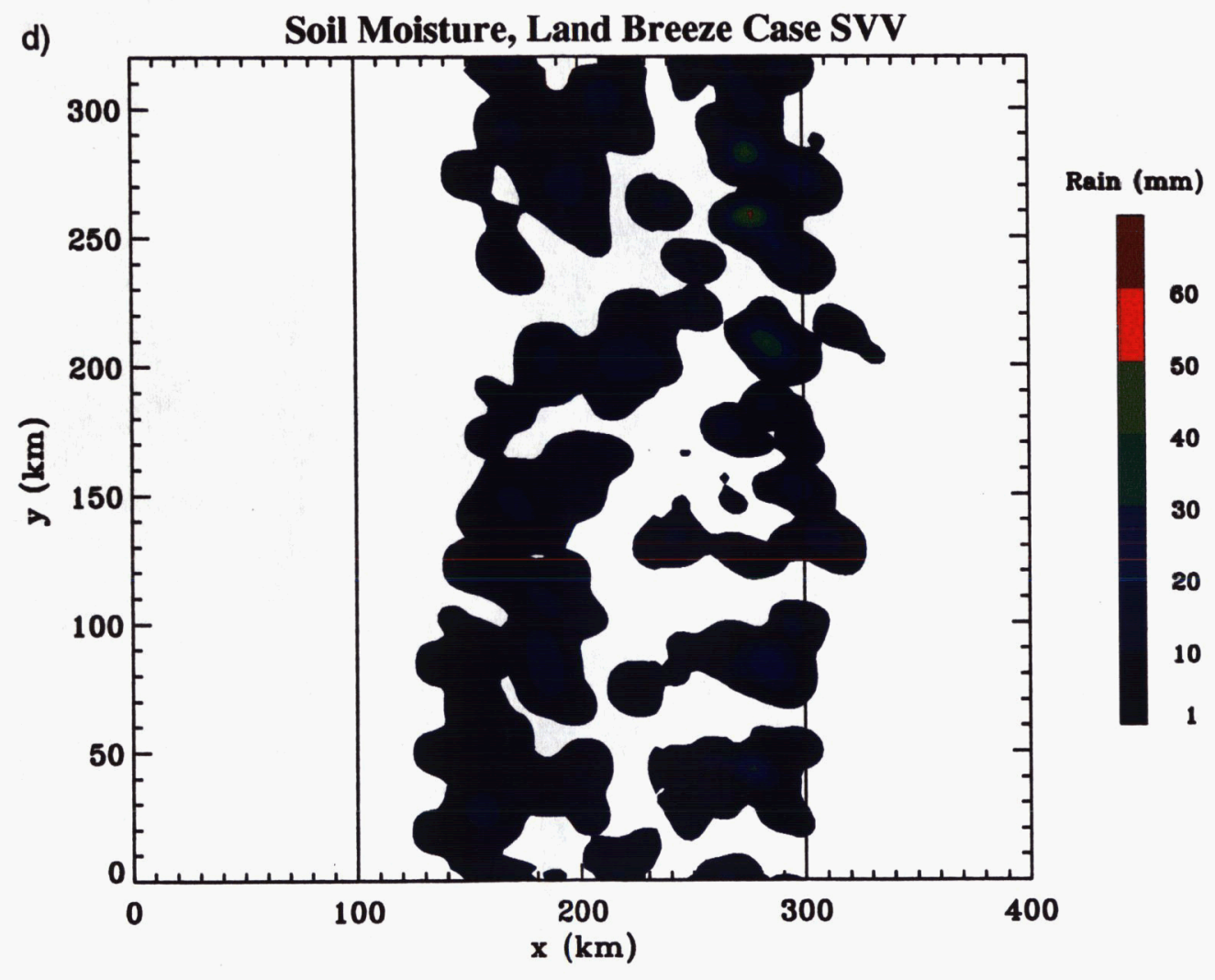

Figure 7: Continued. 


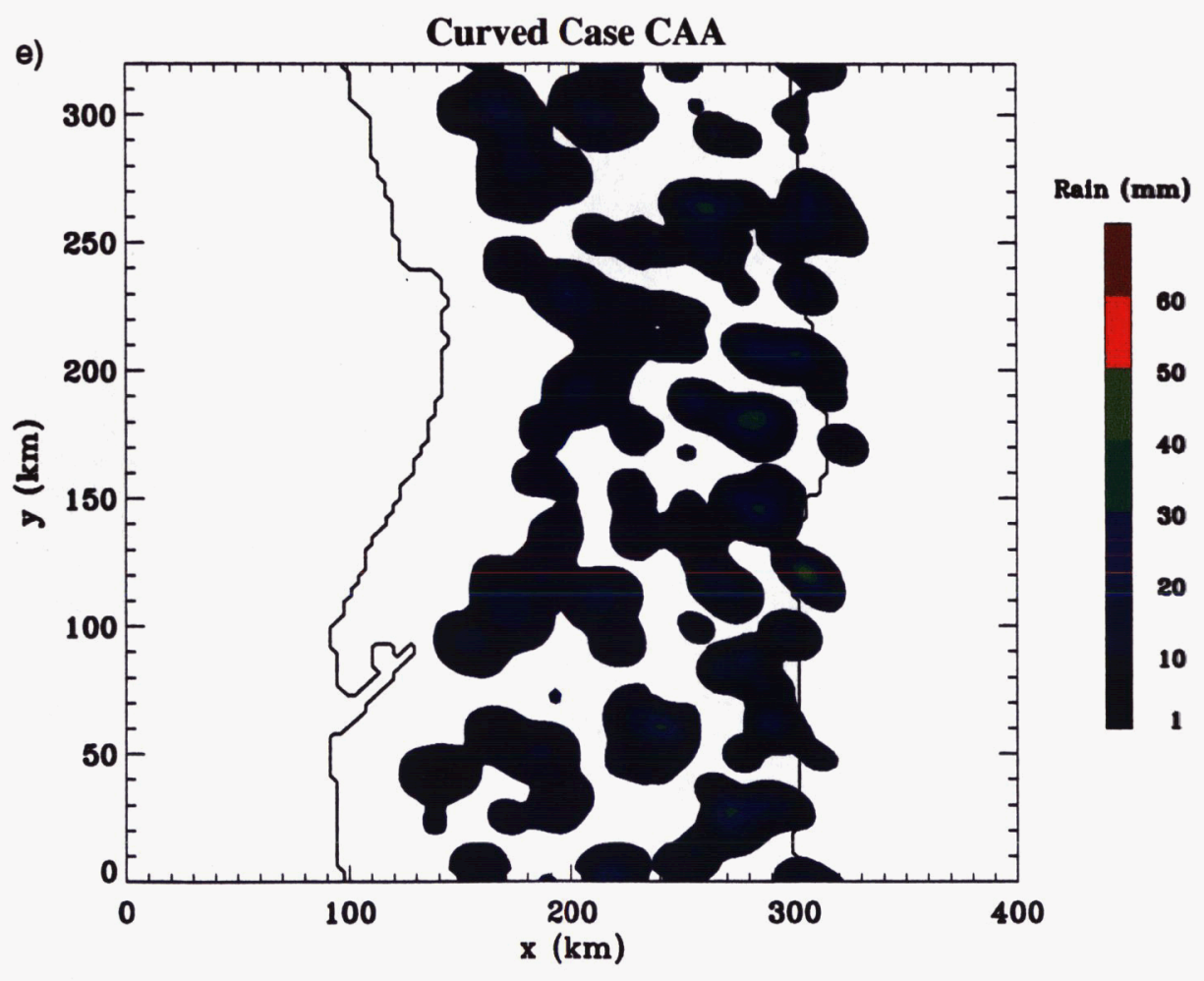

Figure 7: Continued. 


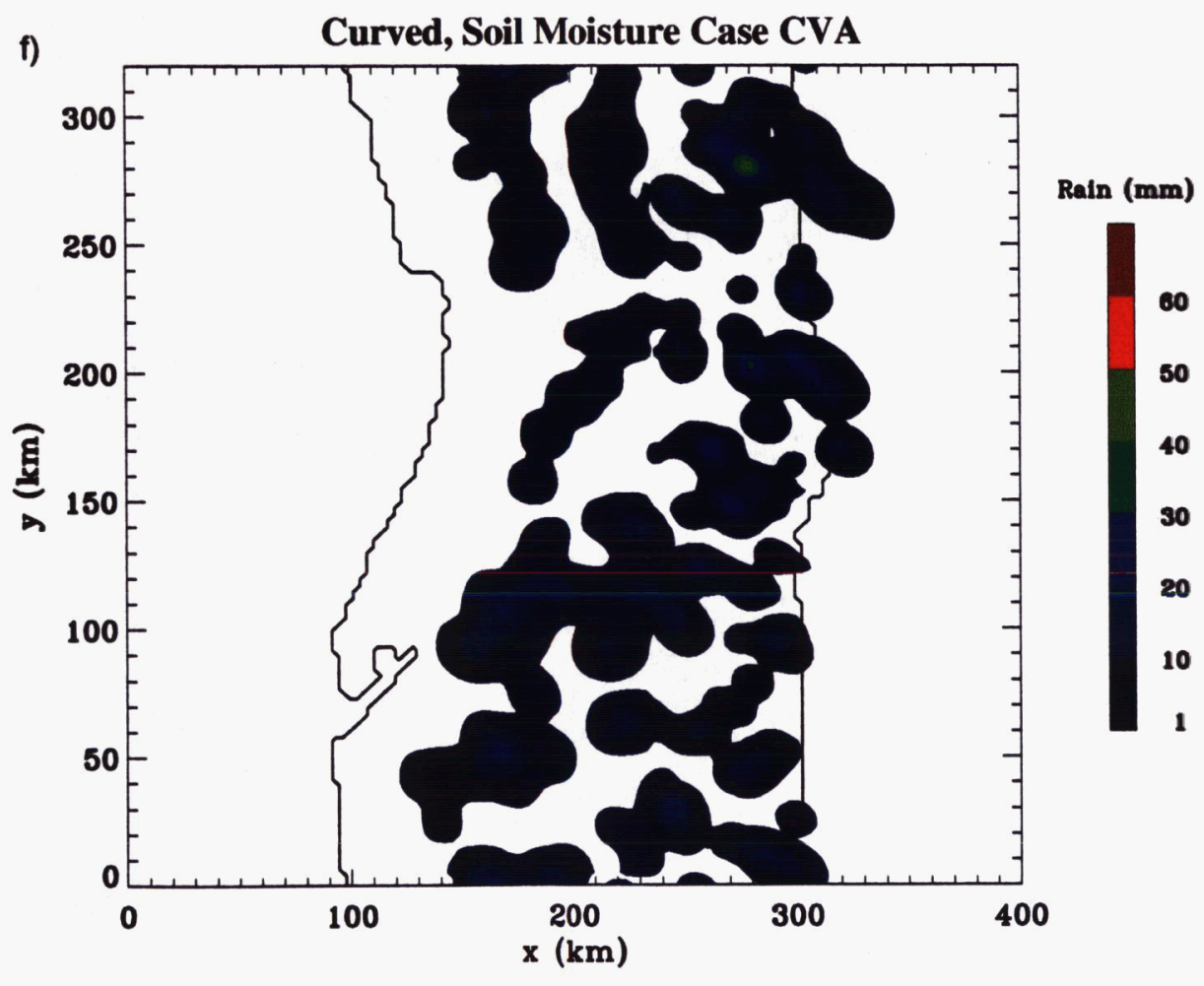

Figure 7: Continued. 


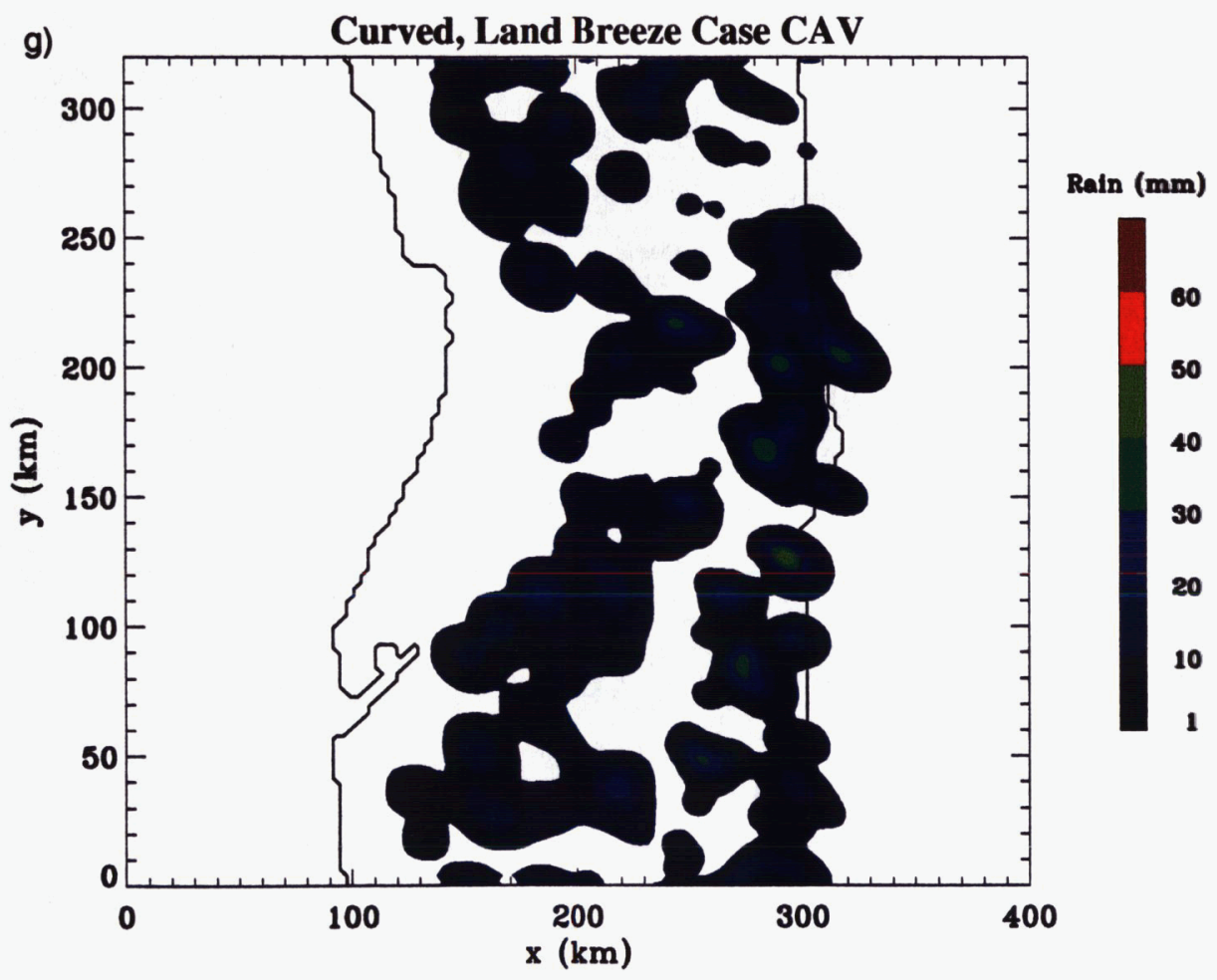

Figure 7: Continued. 


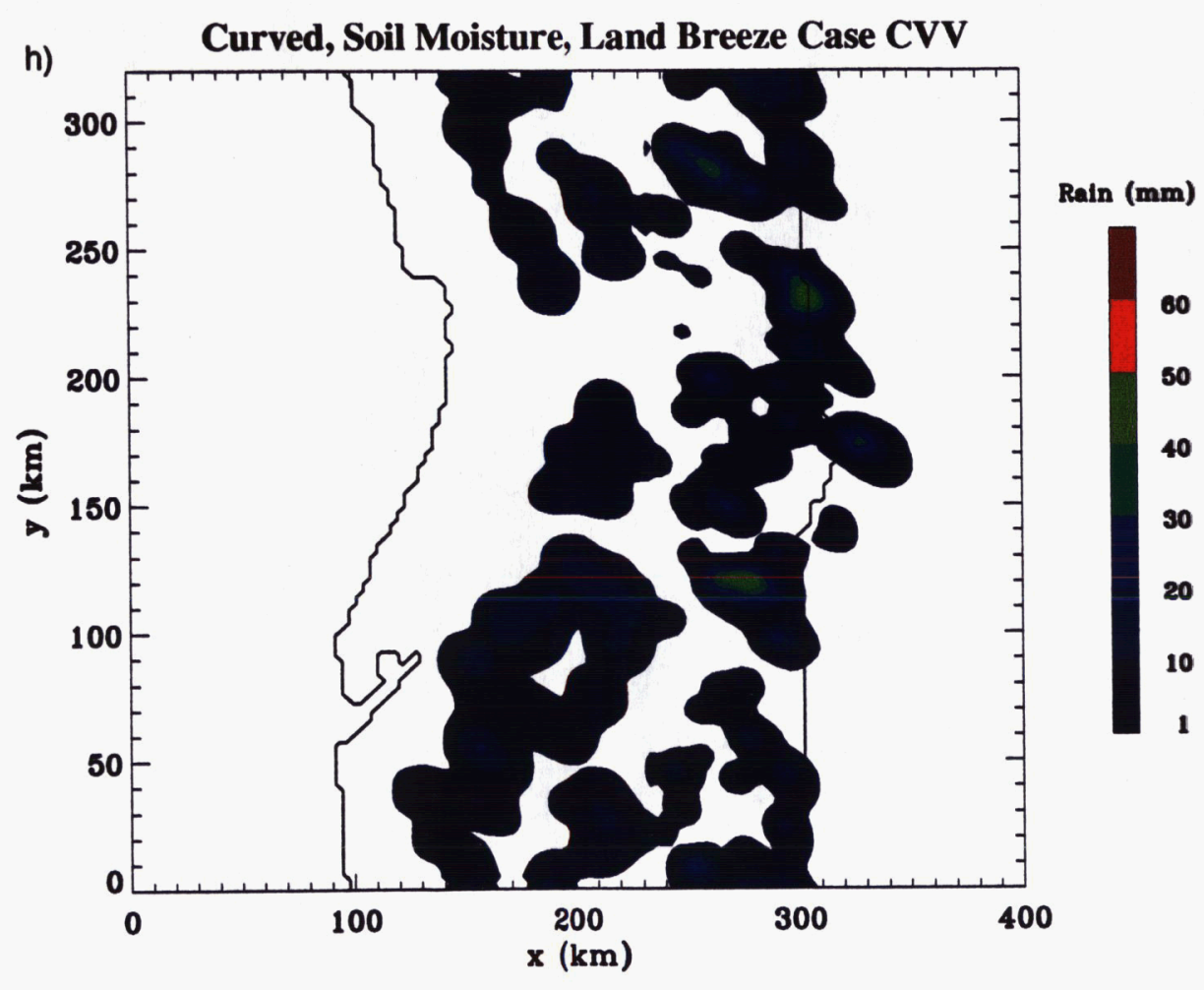

Figure 7: Continued. 

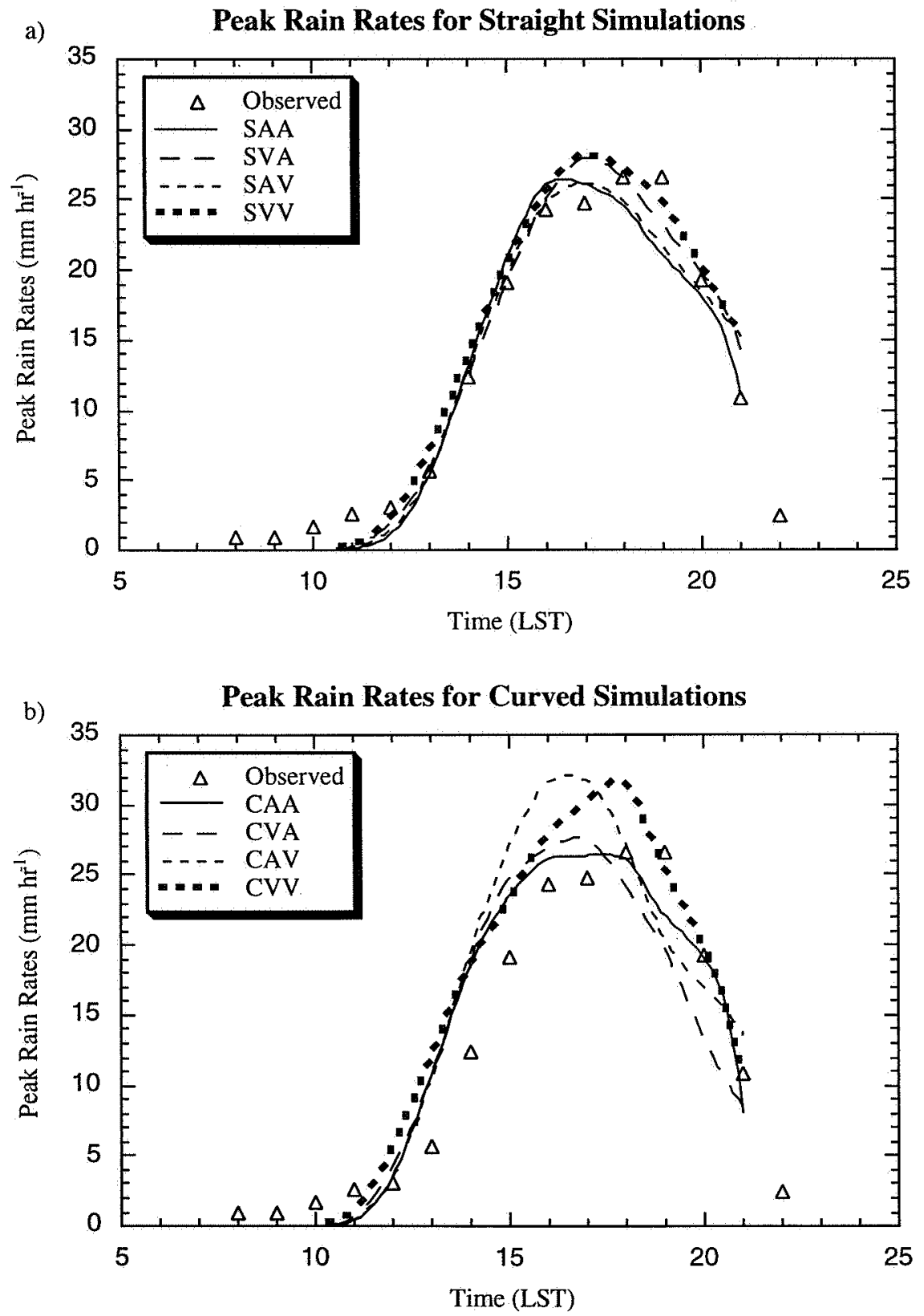

Figure 8: Peak rain rates $\left(\mathrm{mm} \mathrm{hr}^{-1}\right)$ vs. local time for a) straight coastline simulations, and b) curved coastline simulations. Triangles indicate observed peak rain rates from rain gauge measurements. 


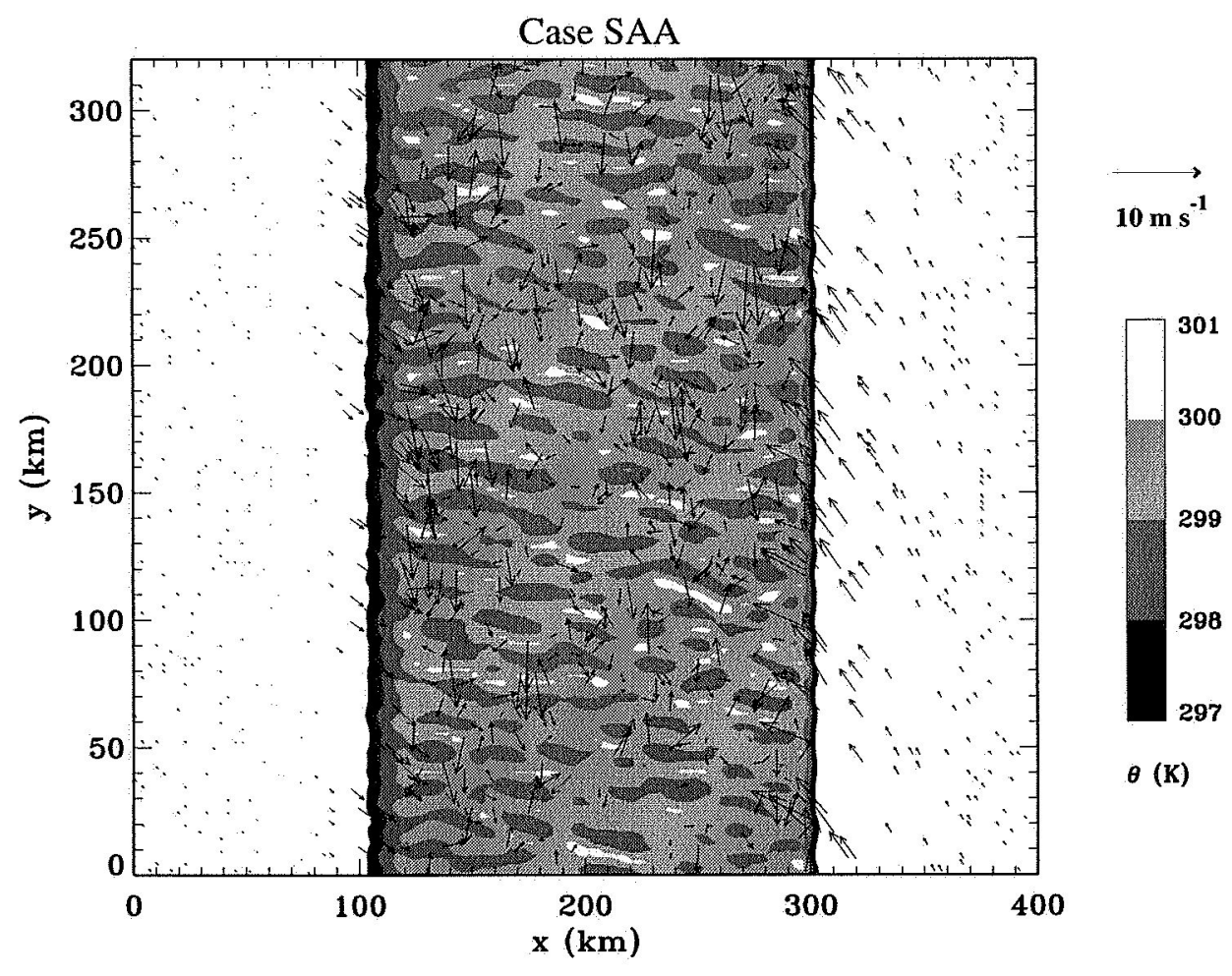

Figure 9: Potential temperature $\theta$ (over land only) and perturbation horizontal winds at 80 meters height at 11 LST for a) simulation SAA and b) simulation SVA. 


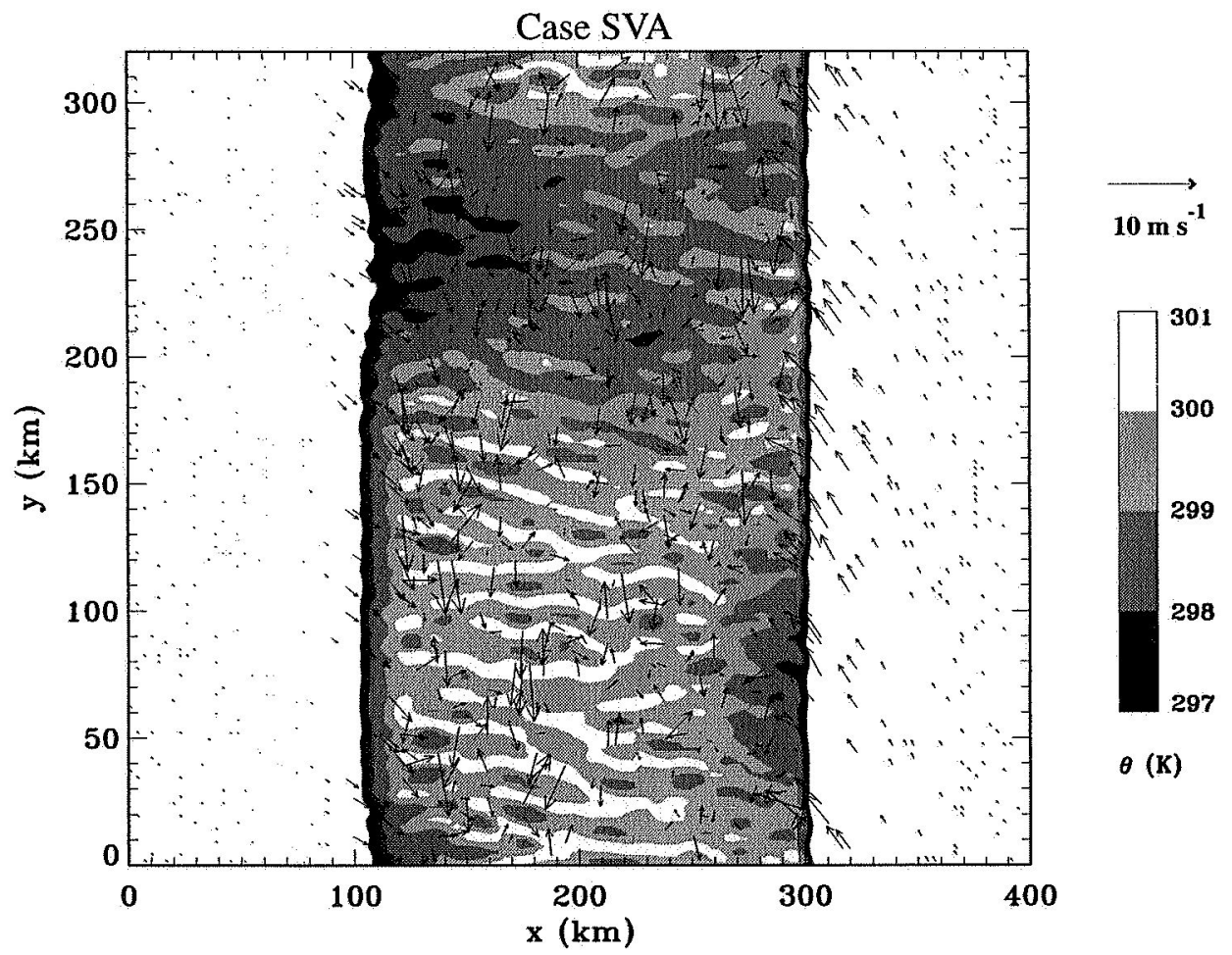

Figure 9: Continued. 

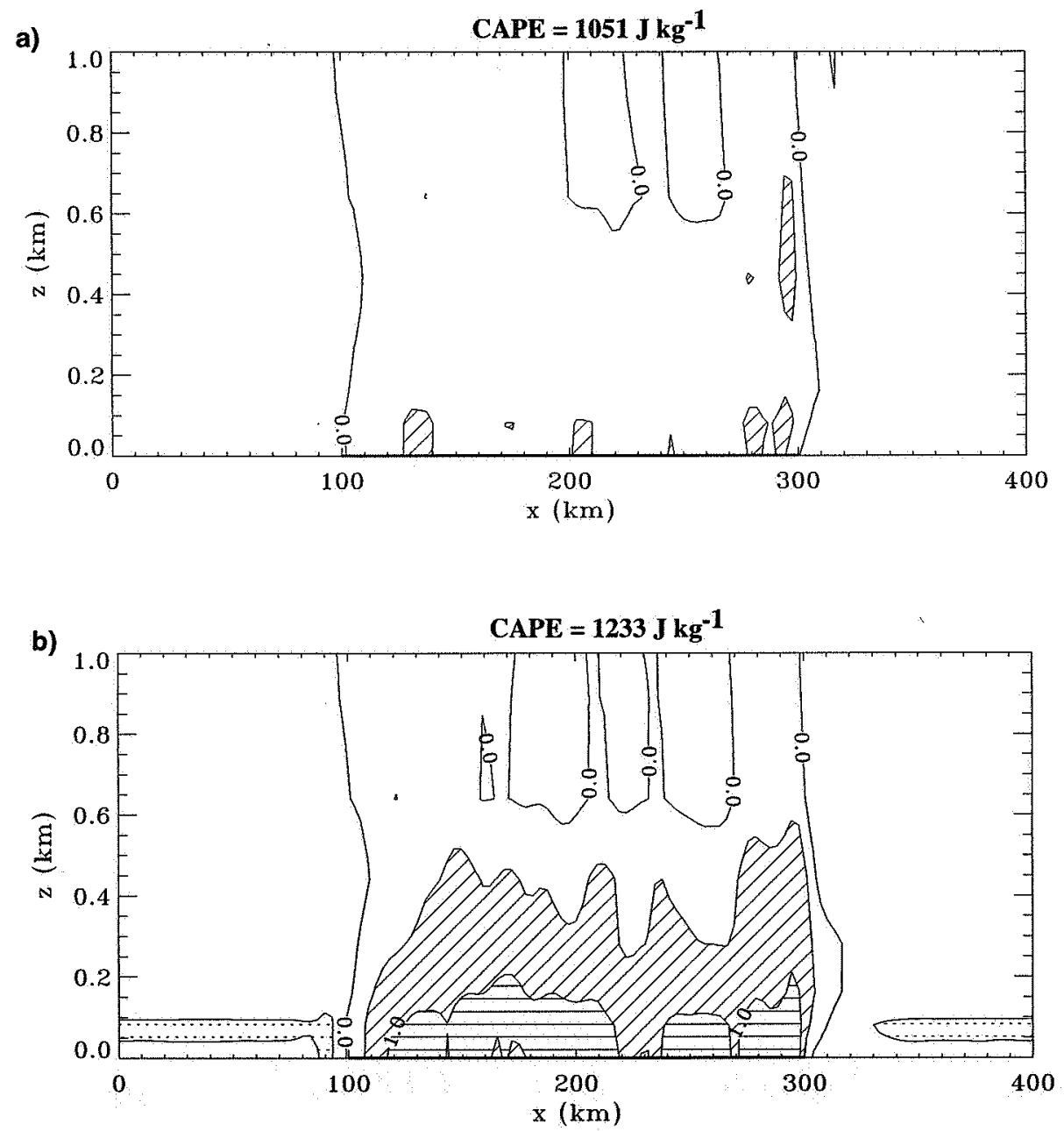

Figure 10: Water vapor mixing ratio perturbation at $y=273 \mathrm{~km}$ in the lowest $1 \mathrm{~km}$ at 10 LST for simulation a) SAA and b) SVA. The contour interval is $0.5 \mathrm{~g} \mathrm{~kg}^{-1}$. The convectively available potential energy (CAPE) averaged across the peninsula at $y=273 \mathrm{~km}$ is also shown. 


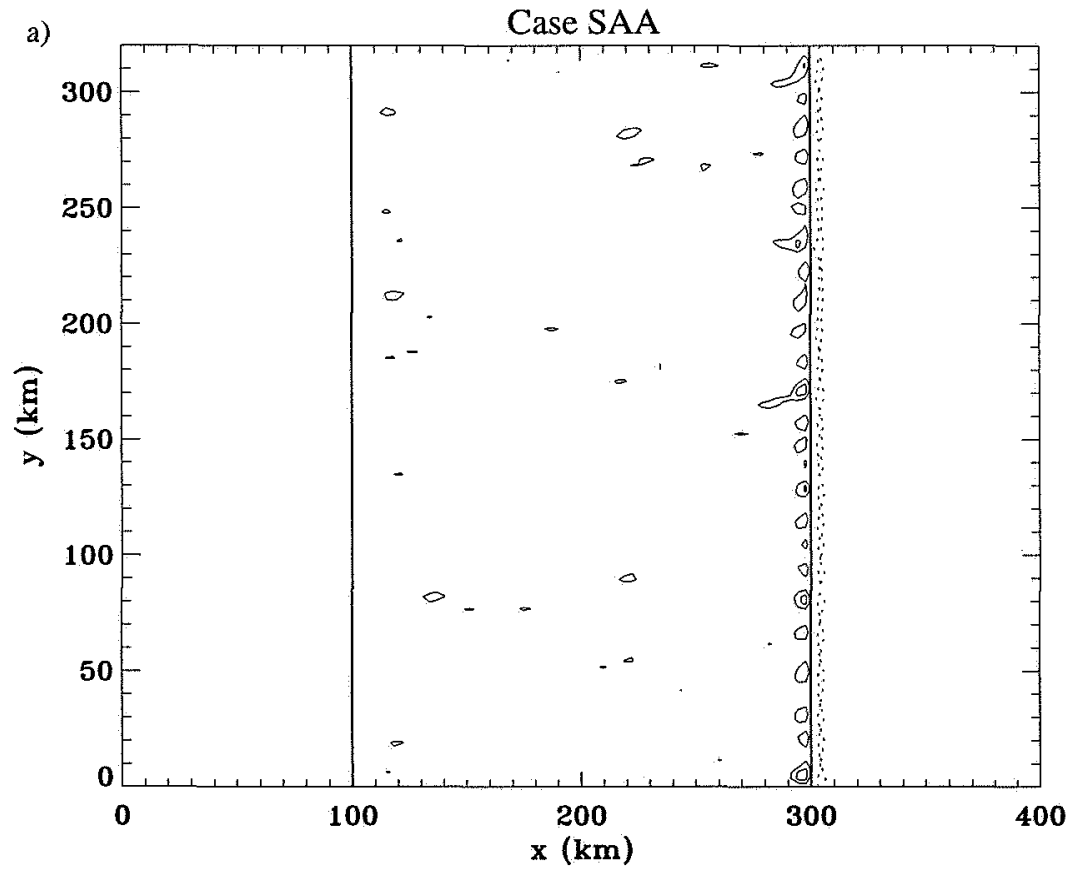

Figure 11: Low-level convergence below $440 \mathrm{~m}$ altitude at $10 \mathrm{LST}$ for simulation a) SAA, and b) CAA. Solid contour lines indicate convergence and dotted lines indicate divergence. The contour interval is $0.001 \mathrm{~s}^{-1}$. 


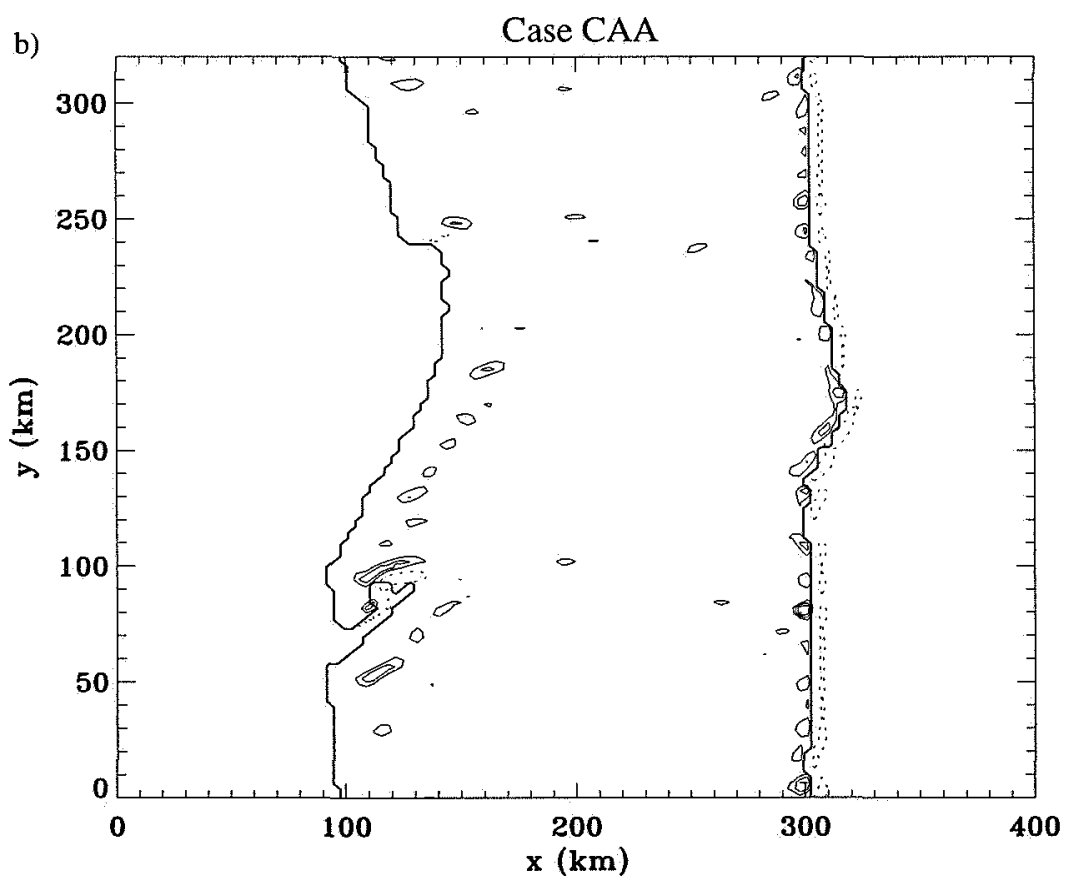

Figure 11: Continued. 